(c) 2008 Elsevier B.V. All rights reserved.

\title{
Role of tidal pumping on nutrient cycling in a temperate lagoon (Arcachon Bay, France)
}

\author{
Jonathan Deborde ${ }^{a,}{ }^{*}$, Pierre Anschutz ${ }^{a}$, Isabelle Auby ${ }^{b}$, Corine Glé ${ }^{a}$, Marc-Vincent \\ Commarieu $^{a}$, Daniele Maurer ${ }^{b}$, Pascal Lecroart ${ }^{a}$ and Gwenaël Abril ${ }^{a}$
}

\author{
aUniversité de Bordeaux I, CNRS, UMR 5805 Environnements Paléoenvironnements OCéaniques (EPOC), \\ avenue des facultés, 33405 Talence, France \\ baboratoire IFREMER DEL/AR, Quai du Commandant Silhouette, 33120 Arcachon, France
}

*: Corresponding author : J. Deborde, email address : j.deborde@epoc.u-bordeaux1.fr

\begin{abstract}
:
The hypothesis of nutrient-rich pore-waters seeping at low tide through sediments to channel waters, which drain tidal flats during ebb, was evaluated in the Arcachon lagoon. The back of the bay is affected by freshwater inputs and underground freshwater discharges. The upper part of tidal flat consists of permeable sandy sediments, which are covered by a muddy sediment layer on the lower part. Permeable sediments outcrop in the bed of channel web. Surface water chemistry and early diagenesis processes in sediment were estimated by collecting channel web waters and cores on a tidal flat and in channels at different seasons and time scales. Waters from tidal creeks are underoxygenated, and enriched in reduced solutes. Muddy sediments showed evidences of strong organic matter mineralization and bioturbation. Underlying permeable sandy sediments revealed as well evidences of an enrichment of inorganic nutrients, and dilution with fresh continental groundwater. During ebb, tidal creek waters stem from mudflats by seeping of anoxic pore-waters, and from permeable sediments by advection of reduced waters. A rough estimation shows that the yearly contribution of this tidal pump of pore-waters for dissolved inorganic phosphorus (DIP) and ammonia inputs is of the same order of magnitude than river inputs for the studied part of the bay. Extrapolated to the whole Arcachon lagoon, pore-water discharge at low tide supplies to water column at least 556 $\mathrm{kmol} \mathrm{yr}-1$ and $18300 \mathrm{kmol} \mathrm{yr}-1$ of DIP and NH4+, respectively. Tidal drainage at low tide represents therefore a minimal contribution of recycled nutrient of $55 \%$ for DIP and $15 \%$ for dissolved inorganic nitrogen to the lagoon.
\end{abstract}

Keywords: Tidal pump; Tidal creek water; Organic matter mineralization; Phosphorus; Nitrogen; Porewaters seeping; Arcachon Bay 


\section{1. Introduction}

Lagoon environments are highly dynamic systems controlled by physical processes and

3 subjected to marine and continental influences. They play a key role as spawning grounds for

4 fish and shellfish, and have been extensively exploited for aquaculture, fishing, tourism ...

5 Eutrophication is a naturally occurring process in most lagoons because of their function as a

6 sink for nutrient inputs from land and sea (De Wit et al., 2001). Thus, processes controlling

7 nutrient levels and distributions in lagoon environments must be understood to assess the

8 impact of human activities and global natural change on the chemical cycling and ecology of

9 these coastal ecosystems.

In lagoon ecosystems, where depth is low and intertidal zone is extended, the sediment

becomes the central unit of biogeochemical nutrient cycles and intense biological productivity.

12 During immersion, numerous studies demonstrated complex interactions and high exchanges

13 between sediment and overlying water occurring in tidal environments (Falcao and Vale, 1995;

14 Rocha et al., 1995; Rocha, 1998; Morin and Morse, 1999; Mortimer et al., 1999; Welsh et al.,

15 2000; Sakamaki et al., 2006). The coupling between benthic processes and exchanges with

16 water is linked to benthic production and deposition of organic matter, subsequent

17 remineralization of organic matter with release of inorganic nutrients to pore-waters, and

18 transport of dissolved nutrients back into overlying water column (Jahnke et al., 2003;

19 Sakamaki et al., 2006). Thus, sediments are either sinks or sources of nutrients derived from

20 external inputs and internal recycling processes. Early diagenesis products are transported to

21 the water column through several processes. In addition to spontaneous molecular diffusion at

22 the sediment water interface, transport of solute by bioturbation (irrigation from burrows and

23 biodiffusion) and discharge of advective groundwater or seawater from bottom permeable

24 sediment layers take place (Simmons, 1992; Huettel et al., 1998; Moore, 1999; Koretsky et al.,

25 2002; Charette et al., 2005; Grigg et al., 2005; Meysman et al., 2006). During ebb, a large

26 channel web drains intertidal flats. Sediment-channel water exchanges can be an important

27 pathway for nutrient cycles and budget for lagoons (Agosta, 1985). 
1 The present study focuses on the chemical composition of tidal creek waters that drain

2 intertidal mudflats during ebb in a mesotidal coastal lagoon. We observed first that most of

3 these creeks were not connected to surface flowing continental waters. Second, at low tide, and

4 before flood tide reached the creeks, the runoff of flowing waters could not be explained by

5 surface water eluviation. These observations suggested that waters flowing in tidal creeks

6 originated partly from nutrient-rich pore-waters. Our objective was to verify this hypothesis,

7 and to estimate the impact of these waters on the global nutrient cycle of the lagoon. Tidal

8 creek waters were compared to samples collected in a channel connected to a river and to

9 waters collected at high tide and during tide cycles. The connection between tidal creek waters

10 and pore-water was evaluated by studying early diagenesis products in sediment cores collected

11 on the tidal flat and in permeable channel sediment.

12

13 2. Study site, materials and methods

14 2.1. Arcachon Bay

Arcachon Bay is a mesotidal shallow lagoon of $180 \mathrm{~km}^{2}$ located on the French Atlantic coast $\left(44^{\circ} 40^{\prime} \mathrm{N}, 1^{\circ} 10^{\prime} \mathrm{W}\right.$; Fig. 1). It is a major centre for oyster farming, and recreational activities. It is connected to the Atlantic Ocean by a 2-3 km wide and about $12 \mathrm{~km}$ long channel, that enables important seawater exchanges, estimated at up to $384 \times 10^{6} \mathrm{~m}^{3}$ for each 19 tidal cycle (Plus et al., 2006). The tide is semi-diurnal and the tidal amplitude ranges from 1.1 $20 \mathrm{~m}$ to $4.9 \mathrm{~m}$ (Gassiat, 1989). At low tide, in the inner lagoon $\left(156 \mathrm{~km}^{2}\right)$, tidal channels drain large tidal flats $\left(115 \mathrm{~km}^{2}\right)$. The maximum water depth of main channels is $20 \mathrm{~m}$. About $70 \mathrm{~km}^{2}$ of tidal flats are covered by Zostera noltii meadows (Auby and Labourg, 1996; Blanchet et al., 2005). At high tide, surface water temperature fluctuates annually between 1 and $30^{\circ} \mathrm{C}$, and surface water salinity between 22 and 32. The intertidal area is exposed to atmosphere for several hours, over each semi-diurnal tidal period. The back of the bay is affected by moderate 26 river inputs and underground freshwater discharges, with a major part coming from the Leyre 27 River, the remaining is provided by secondary streams (Rimmelin et al., 1998). The lower part 
1 of the intertidal zone consists of muddy sediments (grain size: $15-40 \mu \mathrm{m}$ ), and some upper

2 parts are constituted with permeable sandy sediments (grain size: $\sim 250 \mu \mathrm{m}$ ). Permeable sandy

3 sediments also outcrop in the bed of the largest channels.

$4 \quad 2.2$ Study site

5 The studied site consists of a mud flat exposed to the atmosphere $12 \mathrm{~h}$ per day at 6 minimum. About $20 \%$ of the surface area is covered by macrophyte meadows (Zostera noltii 7 and Spartina anglica). The upper part of the tidal flat is covered by more permeable sandy

8 sediments. The study site is cut at southern side by a main channel connected to a small river, 9 which annual mean discharge ranges from 0.120 to $0.160 \mathrm{~m}^{3} \mathrm{~s}^{-1}$ (Fig. 2). The channel represents a small-scale estuary with a salinity gradient from 0 (in the small river) to $15-27$,

11 depending on season. Subsequently, we named this channel the estuarine channel. This channel 12 is also the effluent of a web of tidal creeks (called regionally "estey"), which are not connected 13 to surface continental water flows (Fig. 2). These creeks drain the mud flat at low tide. In the studied area, the main tidal creek was at low tide $400 \mathrm{~m}$ in length, between 0.5 and $3 \mathrm{~m}$ large, with a mean depth of $20 \mathrm{~cm}$. Permeable sandy sediments outcrop in the bed of main branches of creeks and constitute a potential exchange area with underground water. Some portions of

17 the sandy bed were red coloured, suggesting that sand grains were coated with iron oxides. The tidal creek water discharge was measured using a current-meter at several low tide periods, and was between 100 and $1201 \mathrm{~s}^{-1}$ depending on phreatic level (wet-dry season) and tide (neapspring). At low tide, upper parts of muddy intertidal flat present 1 to $10 \mathrm{~m}$ large and about 10 $\mathrm{cm}$ deep tidal pools, where macro algae accumulate (Monostroma obscurum, Enteromorpha sp.).

\subsection{Water sampling}

Table 1 summarises the sampling strategy. Monthly averaged nutrient concentrations at high tide (HT) were measured biweekly in a main channel of the lagoon (Teychan channel, Fig.

26 1) located close to the study site, from December 2002 to January 2004. From March 2005 to 27 September 2006, water samples were collected bimonthly in the estuarine channel along the 
1 salinity gradient and in the major tidal creek web (Fig. 2). The tidal creek web located at north

2 of the estuarine channel was sampled at several points. A minor tidal creek, at south of the

3 estuarine channel, was also sampled at its mouth (Fig. 2). Sampling was performed 1h after

4 slack tide, during ebb tide. Days of sampling were chosen when the low tide (LT) was about at

5 twelve noon. Water samples were also collected in a tidal creek downstream the study site

6 during whole tide cycles at the occasion of a previous investigation in year 1992-1993 (Fig. 1).

7 Sampling was performed at spring tide, when low tide drainage was maximal. Water samples

8 were collected every $15-30 \mathrm{~min}$, from $\mathrm{HT}+3 \mathrm{~h}$ to $\mathrm{LT}+1 \mathrm{~h}$ in winter, spring, summer and fall

9 periods (Auby et al., 1994). During spring collection, the sampling was extended to the

10 nocturnal low tide. Water samples were collected using a $50 \mathrm{ml}$ syringe and were immediately

11 filtered through a $0.2 \mu \mathrm{m}$ cellulose acetate syringe-filter, and kept at $4^{\circ} \mathrm{C}$ for nutrient analysis.

12 Nutrient analyses (N, P and Si dissolved species) were performed back in the laboratory, the

13 same day. An aliquot was acidified $\left(\mathrm{HNO}_{3}\right)$ for dissolved metal analysis. Salinity, $\mathrm{pH}, \mathrm{O}_{2}$

14 saturation, and water temperature were measured during the different sample collections.

$15 \quad$ 2.4. Sediment sample processing

16 In May 2005, July 2005 and February 2006, we collected at low tide two $20 \mathrm{~cm}$ long

17 cores at the level of red sand zone: one in sandy bed of the creek, the other on the mud flat, on

18 edge of the creek (Fig. $2 \&$ Table 1). Sub-samples were taken with $1 \mathrm{~cm}$ resolution from

19 surface to $10 \mathrm{~cm}$, and with $2 \mathrm{~cm}$ resolution for the rest of the core. For each level, another sub-

20 sample was immediately sealed in a preweighed vial and frozen under inert atmosphere for

21 further analyses of solid fraction and water content determination. Pore-waters were extracted

22 by centrifuge at $4000 \mathrm{rpm}$ for 20 min under inert $\mathrm{N}_{2}$-atmosphere. For impermeable sediments,

23 the supernatant was immediately filtered $(0.2 \mu \mathrm{m}$ cellulose acetate syringe-filter). For sandy

24 sediments, we used centrifuge $0.2 \mu \mathrm{m}$ filter-vials. An aliquot of filtered interstitial waters was

25 acidified with $\mathrm{HNO}_{3}$ for dissolved $\mathrm{Fe}$ and $\mathrm{Mn}$ analysis. A second aliquot was frozen at $-25^{\circ} \mathrm{C}$

26 for nutrient analysis. The possibility that traces of oxygen have affected concentrations of

27 reduced elements during slicing and filtration can not be excluded. 


\subsection{Laboratory analysis}

Dissolved nitrate $\left(\Sigma \mathrm{NO}_{3}{ }^{-}=\mathrm{NO}_{3}{ }^{-}+\mathrm{NO}_{2}{ }^{-}\right)$, ammonia and $\Sigma \mathrm{CO}_{2}$ were analysed by Flow Injection Analysis (FIA) according to standard methods (Anderson, 1979; Hall and Aller, 1992). Precisions are $\pm 10 \%$ for $\Sigma \mathrm{NO}_{3}{ }^{-}$and $\pm 5 \%$ for $\mathrm{NH}_{4}{ }^{+}$and $\Sigma \mathrm{CO}_{2}$. Dissolved silicate, phosphate (DIP), and iron were measured by colorimetric procedures (Mullin and Riley, 1955; Murphy and Riley, 1962; Stookey, 1970; Strickland and Parsons, 1972). The precision for these methods are $\pm 5 \%$. Dissolved silicate concentrations of sediment pore-waters, but not surface waters, may have been affected by the conditioning of samples by deep-freezing before analyses. Sulphate was analysed according to a nephelometric method adapted from Rodier (1976) with a precision of about 5\%. Dissolved manganese was measured by flame atomic adsorption spectrometry (Perkin Elmer AA 300) with $\pm 5 \%$ precision. Additional data of water flow for the major river of Arcachon Bay watershed were provided by the Direction Régionale de l'Environnement-Service de la Gironde (DIREN).

Sediment was freeze-dried and the weight loss was used to calculate water content. The dried solid was homogenized for solid-phase analysis. An ascorbate reagent was used to remove from the sediment the most reactive Fe (III) phases $\left(\mathrm{Fe}_{\text {asc }}\right)$, all Mn (III,IV) oxides and oxihydroxides $\left(\mathrm{Mn}_{\mathrm{asc}}\right)$, and associated phosphorus $\left(\mathrm{P}_{\mathrm{asc}}\right)$ (Kostka and Luther, 1994; Anschutz et al., 1998; Deborde et al., 2007). A separate extraction was carried out with $1 \mathrm{M} \mathrm{HCl}$ to determine acid-soluble $\mathrm{Mn}$ and $\mathrm{Fe}\left(\mathrm{Fe}_{\mathrm{HCl}}, \mathrm{Mn}_{\mathrm{HCl}}\right)$. This reagent was used to dissolve amorphous and crystalline Fe and Mn oxides, carbonates, hydrous aluminium silicates, and associated phosphorus $\left(\mathrm{P}_{\mathrm{HCl}}\right)$ (Kostka and Luther, 1994). The precision estimated from replicates was $\pm 5 \%$ for $\mathrm{Mn}$ and $\mathrm{P}$, and $\pm 7 \%$ for Fe. Particulate organic carbon $\left(\mathrm{C}_{\text {org }}\right)$, total carbon $\left(\mathrm{C}_{\mathrm{tot}}\right)$, and total sulphur $\left(\mathrm{S}_{\mathrm{tot}}\right)$ were measured on freeze-dried samples by infrared spectroscopy using a LECO C-S 125. Particulate organic carbon was measured after removal of carbonates with $2 \mathrm{M} \mathrm{HCl}$ during $24 \mathrm{~h}$ from $50 \mathrm{mg}$ of powdered sample. Inorganic carbon is the difference between total carbon and particulate organic carbon. The precision of these analyses was $\pm 0.02 \mathrm{wt} \%$. 


\section{3. Results}

\section{3.1. Nutrient concentrations of high tide water}

5 (Teychan), ranged from 0.2 to $26 \mu \mathrm{M}$ (mean: $7 \mu \mathrm{M}$ ) for $\mathrm{NO}_{3}{ }^{-}$, from 0.5 to $3.5 \mu \mathrm{M}$ (mean: 1.8

$6 \mu \mathrm{M}$ ) for $\mathrm{NH}_{4}{ }^{+}$, and from 0.2 to $0.4 \mu \mathrm{M}$ (mean: $0.2 \mu \mathrm{M}$ ) for DIP (Fig. 3). Maximum

7 concentrations of nitrogen species were measured in winter and decreased during productive

8 period, while DIP concentrations did not show significant seasonal trends.

\section{3.2. Geochemical composition of tidal creek waters}

Oxygen saturation, $\mathrm{pH}$ and concentrations of studied dissolved species, measured

11 during ebb tide in estuarine and tidal creek waters, are represented versus salinity in Figure 4.

12 For each sampling, creek waters were usually warmer and saltier probably because of

13 shallower depth than estuarine channel, no connection with a river, and higher influence of evaporation processes (Table 2). These characteristics were naturally more pronounced in summer. In summer, the temperature of creek waters reached $32^{\circ} \mathrm{C}$, whereas river water was at about $17^{\circ} \mathrm{C}$. Concentrations of dissolved oxygen were lower in creek waters. Nitrate and sulphate concentrations were aligned on a dilution line in estuarine waters, whereas waters from tidal creeks were generally depleted in sulphate and nitrate relative to a mixing line (Figure 4). The mean $\Sigma \mathrm{NO}_{3}{ }^{-}$concentration of tidal creek was $1.8 \mu \mathrm{M}$, and the concentration never exceeded $6 \mu \mathrm{M}$. At each season, creek waters which drain the tidal flat also were characterized by a high enrichment in reduced solutes and $\Sigma \mathrm{CO}_{2}$ (see Appendix A). Average $\Sigma \mathrm{CO}_{2}$ and $\mathrm{NH}_{4}{ }^{+}$concentrations were respectively up to eight and four times higher than in the estuarine channel. Maximum $\mathrm{NH}_{4}{ }^{+}$concentrations were observed in March 2005, reaching 300

$24 \mu \mathrm{M}$ and $50 \mu \mathrm{M}$ in the tidal creeks and estuarine channel, respectively. The mean $\mathrm{NH}_{4}{ }^{+}$ 25 concentration was about $100 \mu \mathrm{M}$ in tidal creeks. Same tendencies were noted for dissolved 26 iron, manganese and DIP, with average concentrations twice, three times, and four times higher 27 in creek waters, respectively. The averaged DIP concentration was $1.6 \mu \mathrm{M}$, and the highest 
1 concentrations reached $7 \mu \mathrm{M}$. Dissolved siliceous concentrations did not show clear differences

2 between both creek systems. Waters from tidal pools sampled in upper parts of the tidal flat

3 were characterized by a very high $\mathrm{O}_{2}$ saturation (ranges: 180 and $305 \%$ ), associated with a pH

4 values higher than 8 (Table 1). They were generally depleted in nutrients and reduced dissolved

5 compounds during the daytime period.

\section{$6 \quad 3.3$. Variations of creek water geochemistry during tide cycles}

7 In Arcachon bay, $\Sigma \mathrm{NO}_{3}{ }^{-}$are principally supplied by rivers, and concentrations increase

8 with freshwater discharge (Rimmelin et al. 1998; De Wit et al., 2005). Thus, $\Sigma \mathrm{NO}_{3}{ }^{-}$

9 concentrations were maximal in tidal creek during wet periods (fall and winter, Fig. 5). On a

10 tide cycle scale, increase of $\Sigma \mathrm{NO}_{3}{ }^{-}$in fall corresponded to decrease of salinity, i.e. dilution with

11 river waters during ebb. $\mathrm{NH}_{4}^{+}$and DIP concentrations always gradually increased in creek

12 water during end of ebb to reach a maximum at low tide. Values were higher during nocturnal

13 ebb (Fig. 6). This increase of concentration was independent of salinity. Measurements of

14 dissolved iron and manganese concentrations were below detection limit (data not shown).

\subsection{Diagenetic profiles in sediment cores}

Dissolved and particulate species profiles measured on sediment cores collected on muddy edge of the creek and in the red sand zone of the creek bed are shown in Fig. 7a and 7b, respectively. The creek edge cores were characterized by a decimetre thick mud layer (mean grain size: 15 to $40 \mu \mathrm{m}$ ), which covered a permeable sandy sediment layer (mean grain size: $270 \mu \mathrm{m})$ (Fig.7a). The mud layer was black. We noted a strong smell of sulphide during sampling and core processing. Previous studies (De Wit et al., 2001), and our own unpublished data showed that the oxic layer was limited to the upper 1 or $2 \mathrm{~mm}$ on the Arcachon Bay mud flat. Salinity and sulphate concentrations in muddy and sandy layers showed a decreasing gradient from the surface to the bottom core for the sampling times. Salinity decrease was less marked in summer. In muddy sediments, early diagenesis recycled products, such as $\Sigma \mathrm{CO}_{2}$, $\mathrm{NH}_{4}{ }^{+}$, DIP, dissolved iron and manganese increase directly below the surface. $\Sigma \mathrm{CO}_{2}$ and $\mathrm{NH}_{4}{ }^{+}$ concentrations exceeded $3 \mathrm{mM}$ and $200 \mu \mathrm{M}$ below $2 \mathrm{~cm}$ depth, respectively, and gradually 
1 increased below. DIP, dissolved iron and manganese showed high concentrations in muddy

2 layer, in comparison to underlying sands, where concentrations never exceeded $3 \mu \mathrm{M}, 5 \mu \mathrm{M}$

3 and $1 \mu \mathrm{M}$, respectively. Nitrate concentrations were lower than $5 \mu \mathrm{M}$ in the muddy anoxic

4 sediment. Profiles of $\mathrm{P}_{\mathrm{asc}}, \mathrm{P}_{\mathrm{HCl}}, \mathrm{Fe}_{\mathrm{asc}}$, and $\mathrm{Fe}_{\mathrm{HCl}}$ showed the same pattern, with maxima in

5 muddy layer of about $12,22,240$ and $500 \mu \mathrm{mol} \mathrm{g}^{-1}$, respectively. In sands, they decreased to

6 reach values close to $0.5,2,10,20 \mu \mathrm{mol} \mathrm{g}{ }^{-1}$, respectively. The mud layer generally presented

7 high contents of particulate sulphur (>1.5\%) and organic carbon (>3\%), which represented the

8 major part of total particulate carbon. The core collected in January 2006 showed lower values

9 of particulate phosphorus, iron, manganese, carbon and sulphur in the muddy layer. This

10 change may be explained by a modification of the studied sediment. In January 2006, the mud

11 was enriched in sandy particles, and the mean grain size was $50 \mu \mathrm{m}$. This observation reveals

12 the high heterogeneity and the seasonal evolution of the surface sedimentation on tidal flat.

13 Cores collected on the bed of the creek consisted of permeable sandy sediments with a $4 \mathrm{~cm}$

14 surface layer of red sands (Fig. 7b). This layer corresponded to the high values of $\mathrm{Fe}_{\text {asc }}$ and

$15 \mathrm{Fe}_{\mathrm{HCl}}$ profiles (about 25 and $50 \mu \mathrm{mol} \mathrm{g}^{-1}$, respectively). Concentrations decreased rapidly below

$164 \mathrm{~cm}$ depth to reach about 10 and $15 \mu \mathrm{mol} \mathrm{g} \mathrm{g}^{-1}$, respectively. Comparable vertical distributions

17 were observed for $\mathrm{P}_{\mathrm{asc}}$ and $\mathrm{P}_{\mathrm{HCl}}$. For the three sampling times, DIP concentrations were low and

18 nearly constant with depth, close to $1.0 \mu \mathrm{M}$. Dissolved iron also was constant with depth,

19 around $6.0 \mu \mathrm{M}$, and higher than measured in surface waters (3.2 $\mu \mathrm{M})$. In January 2006,

20 dissolved iron concentration drastically increased from $33 \mu \mathrm{M}$ in surface water to about 670

$21 \mu \mathrm{M}$ two cm below sediment-water interface. Profiles of $\mathrm{Mn}^{2+}, \mathrm{Mn}_{\mathrm{ASC}}$ and $\mathrm{Mn}_{\mathrm{HCl}}$ remained

22 constant at values close to zero, except for the July 2005 core, where dissolved manganese

23 increased with depth below the red sand layer. Sandy sediments $C_{\text {org }}, C_{\text {tot }}$, and $S_{\text {tot }}$ contents

24 were in the range of $0.1-0.2 \%$. Concentrations of nitrate were generally higher just below

25 sediment water interface than in overlying creek water. At depth, nitrate concentrations

26 decreased. Ammonia increased rapidly in the red sand layer, and then it remained constant 
1 close to $160 \mu \mathrm{M}$, which was higher than surface water concentrations. We also measured a

2 decreasing gradient of salinity and sulphate in winter and spring.

\section{Discussion}

\subsection{Sedimentology and consequences on pore-water seeping}

Sedimentology of the study site strongly influences water fluxes across sediment-water interface during low tide. During immersion, permeable sediments of upper parts of the intertidal zone (Fig. 2) become saturated with seawater by infiltration. Permeability of sand makes possible advective pore-water transport. At low tide, when pore-water table in upper sandy beach decreases, sands become unsaturated with water in the upper centimetres below the sediment surface. We observed in sands of studied cores that dilution of pore-waters with desalted waters increased during wet seasons. Therefore, underlying sands were probably affected by underground freshwater discharges, suggesting existence of a subterranean estuary more or less efficient, depending both on tide situation and season, as observed on other tidal beaches (Huettel et al., 1998; Huettel and Rusch, 2000; Charette et al., 2005). Underlying sands outcrop in the bed of studied channels. During ebb, i.e. during our sampling time, as pore-water table level drops slower than seawater level, a hydraulic gradient occurs (Nielsen, 1990). This pressure gradient causes an advective flux of pore-waters from upper sandy parts to lower parts of the flat below muddy layer. The intensity of this flux depends on hypsometric gradient. Finally, pore-waters can feed the tidal creek web at resurgence zones. Future studies on this site with geochemical tracers would enable us to estimate by modelling mean water residence time during this underground run.

Downstream, where the flat consists of impermeable muddy sediments overlaying permeable sandy sediments, we noticed important bioturbation activity driven by numerous burrows of annelida, bivalves, gasteropodan, and crabs (Blanchet et al., 2004; Blanchet et al., 2005; Cottet et al., 2007). In this area, density of annelids and bivalves burrows exceeds more than 20000 ind $\mathrm{m}^{-2}$ (Blanchet et al., 2004). Consequently, profiles of reactive particulate and 
1 aqueous species in muddy sediments are controlled by early diagenetic reaction and transport

2 by molecular diffusion, but also by advective bioturbation (Berner and Westrich, 1985; Wang

3 and Van Cappellen, 1996). Due to cohesive nature of sediment and its low permeability, the

4 mud remains saturated with seawater at low tide. During emersion, the tidal flat is exposed to

5 atmosphere for several hours, and we observed that burrows became ideal ducts for pore-water

6 seeping. Our sampling of water at low tide took place always around noon time. Uncovered

7 mud flat was exposed to light before sampling, and it was thus heated. Consequently, most of

8 the year, temperature of exposed mud flat was higher at low tide, in contact with atmosphere,

9 than at high tide in contact with usually cooler flood water (data not shown). Except in winter,

10 the temperature we measured in sampled creeks was higher than the temperature of water at

11 high tide. Salinity of creek waters also was higher than salinity measured down core, in sandy

12 sediments. The salinity was close to what we measured in the upper part of muddy sediments.

13 Temperature and salinity suggest that evaporation occurs at each low tide and that the slow

14 drainage of remaining standing water on surface mud flat is an important source of water for

15 tidal creeks. Therefore, tidal creek waters are the sum of slow run off of standing water, pore-

16 water seeping from muddy sediments, and to a lesser extent, seeping through permeable

17 sediments.

18 4.2. The tidal pump

19 Surface water chemistry shows that there are two hydrous systems with distinct 20 physical and chemical properties at low tide. The main channel is fed by a river and 21 consequently acts as a small scale estuary. The river represents a well oxygenated source of 22 nitrate for the system. Nitrate and sulphate concentrations are aligned on a classical mixing line 23 relative to salinity. On the contrary, the creek waters are under-saturated in oxygen, enriched in 24 reduced and recycled solutes, and globally depleted in sulphate and nitrate relative to a mixing 25 line vs. salinity at low tide (Fig. 4). Creek waters are obviously different from waters collected 26 at high tide (Fig. 3). 
1 Sediment cores were collected without replicates $(\mathrm{n}=1$, for each season), and thus

2 could not be used to quantitatively estimate properties such as fluxes or stocks of chemical

3 species. Cores are however considered to be representative of pore-water nature and of

4 occurrence of early diagenetic processes because lithology of the studied zone is homogeneous.

5 Muddy sediment core chemistry suggests that sub-oxic and anoxic processes of organic matter

6 mineralization occur (Fig. 7a). Underlying permeable sandy sediments show as well evidences

7 of an enrichment of inorganic nutrients. Dilution of pore waters with fresh continental

8 groundwater (Fig. 7b) cannot explain high nutrient concentrations in sandy sediments, because

9 salinity profiles and nutrient profiles are uncorrelated. Thus, reduced solutes and inorganic

10 nutrients can be transferred from muddy sediments to permeable sandy sediments by molecular

11 diffusion at the sand-mud boundary, or by burrows that cross this boundary. Additionally,

12 organic matter mineralization can occur also within permeable sediments located on the bed of

13 the creek. Indeed, during flood, fresh organic matter can be introduced to the sediment by

14 advective infiltration in upper sands, as observed elsewhere (Huettel and Rusch, 2000; Rusch et

15 al., 2000). Previous studies have also shown that during low tide, intertidal sand flats lead

16 accumulation of metabolic products (Rocha, 1998; Kuwae et al., 2003; Billerbeck et al., 2006a;

17 Billerbeck et al., 2006b). Thus, tidal creek waters show an enrichment in products of early

18 diagenesis processes, especially in ammonium and phosphate. This enrichment occurs at end of

19 ebb whatsoever the season, due to increased influence of sediment-water exchanges on channel

20 water chemical composition (Fig. 5 and 6). Actually, at low tide, creek water consists of

21 sediment pore-waters originating from slow muddy sediment run off, from molecular diffusion,

22 and from advective seeping of anoxic nutrient-rich pore-waters through numerous burrows and

23 permeable sediments, induced by tidal pumping. The small creek sampled on the south side of

24 the estuarine channel drains only a muddy tidal flat. Sandy permeable sediment does not 25 outcrop on the bottom of this creek. The larger tidal creek sampled on the north side drains 26 both mud flat and sandy sediments. Chemical composition of these two creeks is similar, which 27 suggests that muddy sediment pore-waters contribute dominantly to chemical characteristics of 
1 creek waters at low tide. Creek waters enter in estuarine waters and despite dilution, they can

2 supply at each ebb tide the reduced species measured in the estuarine channel and in the rest of

3 the lagoon. Similar observations were recently revealed in another tidal bay, where tidal

4 flushing of bottom water at low tide was evidenced by high concentrations of reduced solutes,

5 such as sulphide, $\mathrm{Fe}^{2+}$ and $\mathrm{Mn}^{2+}$ (Lewis et al., 2007).

6 Permeable sediments at the bottom of the creek are enriched in ascorbate extractable

7 iron oxides (Fig. 7b). The enriched layer probably originate from (re-)oxidation of dissolved

$8 \mathrm{Fe}(\mathrm{II})$ present in reduced pore-waters in contact with overlying oxic waters, as observed on

9 sandy flats by Huettel et al. (1996). The advective transit of reduced groundwater to more

10 oxygenated environment causes a partial active re-oxidation of dissolved iron, and also

11 manganese, which explains the $4 \mathrm{~cm}$ red sand layer noticed at the level of the groundwater

12 resurgence. Phosphorus extracted by the ascorbate solution shows maximum values in this

13 layer. It is well known that iron oxides have a great efficiency for dissolved phosphate

14 adsorption (Krom and Berner, 1980; Sundby et al., 1992; Anschutz et al., 1998). Therefore,

15 formation of iron oxides in sandy sediments represents a trap for dissolved $\mathrm{P}$ that is advected

16 from pore-waters. In the studied creek, we observe that some dissolved Fe(II) escape the

17 sediment, which shows that the surface sediment is not a definite barrier for dissolved Fe.

18 Large concentrations of dissolved Fe(II) were measured in pore-water during wet periods,

19 when the discharge of fresh ground water was significant. During these periods the bottom of

20 sandy sediment was more red-coloured than previous periods and inputs of DIP to tidal creek

21 waters were apparently lower than during summer period (Fig. 5). Flushing of reduced pore-

22 waters and possibly precipitation of authigenic Fe-oxides is probably enhanced in winter,

23 inducing a higher adsorption of phosphorus.

24 During nocturnal tides, nutrient inputs by tidal pumping seem to be higher than during

25 diurnal tides (Fig. 6). This is probably due to a strengthening of anoxic processes and a drop of

26 photosynthetic activity during night. Actually, ammonium and DIP are essential nutrients for

27 benthic primary producers, especially seagrasses. Assimilation of these nutrients under daylight 
1 and during productive periods (Touchette and Burkholder, 2000; Welsh et al. 2000) explain the

2 relative lower values of diurnal tides.

\subsection{Estimation of nutrient inputs by the tidal pump}

Waters that flow at low tide in creeks are advected from sandy and muddy sediment pore-waters. A rough estimation of nutrient fluxes during each low tide triggered by this process can be calculated. During ebb, the mean discharge runoff measured at the outlet of the studied tidal creek web ranges between $0.100-0.120 \mathrm{~m}^{3} \mathrm{~s}^{-1}$. The surface of drained tidal flat is estimated at about $0.114 \mathrm{~km}^{2}$ with satellite images. The mean time during which the mudflat is exposed to air, and during which water outflows downstream in the tidal channel corresponds to $4 \mathrm{~h}$ per tide cycle, i.e. $8 \mathrm{~h}$ per day. Therefore, a total of $2880-3450 \mathrm{~m}^{3}$ of water enriched in recycled products is drained by creeks each day through tidal pumping. This tidal creek water showed mean concentrations of DIP, $\mathrm{NH}_{4}{ }^{+}$and $\Sigma \mathrm{NO}_{3}{ }^{-}$ranging from 1.4 to 2.3, 46.1 to 200.4 and 0.5 to $6.2 \mu \mathrm{M}$, respectively according to season. It represents a contribution of $1.5-2.9$

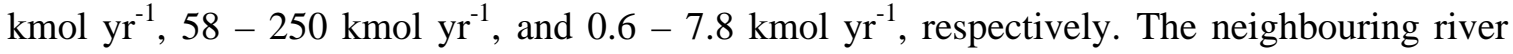
which provides fresh water to the studied small estuary, supplies 0.1 to $0.3,0.9$ to 29.6 and 14.8 to $138.2 \mu \mathrm{M}$ of DIP, $\mathrm{NH}_{4}{ }^{+}$and $\Sigma \mathrm{NO}_{3}{ }^{-}$, respectively. The mean freshwater flow was evaluated at 0.120 to $0.160 \mathrm{~m}^{3} \mathrm{~s}^{-1}$ from a two year monitoring at the river mouth (M. Canton, pers. comm.). The river drains a surface area of $18 \mathrm{~km}^{2}$. A maximum yearly flux of nutrients was estimated at $1.5 \mathrm{kmol} \mathrm{yr}^{-1}$ for DIP, $149 \mathrm{kmol} \mathrm{yr}^{-1}$ for $\mathrm{NH}_{4}{ }^{+}$, and $697 \mathrm{kmol} \mathrm{yr}^{-1}$ for $\Sigma \mathrm{NO}_{3}{ }^{-}$. River remains a major source of nitrate, due to land use in the catchment area, but the tidal pump on the 0.114 $\mathrm{km}^{2}$ studied tidal zone contributes yearly to a DIP and an ammonia source of the same order of magnitude as the river. Therefore, the tidal flat acts as an independent major recycled nutrient source to the ecosystem through pore-water seeping and tidal flat draining. A given surface area of tidal flat supplies as much dissolved $\mathrm{N}$ and $\mathrm{P}$ as a hundred times larger river catchment area.

Our data set allows us to attempt an upscaling exercise in order to estimate the recycled nutrient flux to water column by tidal pumping mechanism for the whole Arcachon Bay. To 
1 extrapolate data from the $0.114 \mathrm{~km}^{2}$ studied part of the tidal flat to the whole intertidal zone of

2 the lagoon $\left(115 \mathrm{~km}^{2}\right)$ we attempt to estimate minimal values. For that, we consider a minimal

3 time during which the tidal pumping takes place during emersion phase, and we take into

4 account the range of average concentrations of recycled nutrient. The time during which

5 intertidal zone is exposed to air, and during which water flows downstream in tidal channels is

$64 \mathrm{~h}$ or less per tide cycle, depending on tidal flat location. For the following calculations, we use

7 1h30min per tide cycle for the whole bay, i.e. $3 \mathrm{~h} \mathrm{~d}^{-1}$ (2 tide cycles per day). Thus, the pore-

8 water discharge by the tidal pumping represents about $398-478 \times 10^{6} \mathrm{~m}^{3} \mathrm{yr}^{-1}$. It supplies

9 about $556-1100 \mathrm{kmol} \mathrm{yr}^{-1}, 18300-95800 \mathrm{kmol} \mathrm{yr}^{-1}$, and $200-2900 \mathrm{kmol} \mathrm{yr}^{-1}$ of DIP, $\mathrm{NH}_{4}^{+}$

10 and $\mathrm{\Sigma NO}_{3}{ }^{-}$, respectively. These values are underestimations, because the selected emersion

11 time is a minimal value. We can compare these values with river inputs. For the whole

12 Arcachon lagoon, freshwater inputs are dominated by rainfalls $(8 \%)$, the Leyre River (73\%)

13 and small streams (18\%), that represent about $104410^{6} \mathrm{~m}^{3} \mathrm{yr}^{-1}$ from a $4000 \mathrm{~km}^{2}$ catchment area

14 (Auby and Labourg, 1996; Rimmelin et al., 1998). Freshwater discharges correspond to a

15 contribution of $460 \mathrm{kmol} \mathrm{yr}^{-1}, 4500 \mathrm{kmol} \mathrm{yr}^{-1}$, and $99000 \mathrm{kmol} \mathrm{yr}^{-1}$ for DIP, $\mathrm{NH}_{4}^{+}$and $\Sigma \mathrm{NO}_{3}^{-}$,

16 respectively (Fig. 8; Rimmelin et al., 1998.). Therefore, according to the above rough

17 estimation, at least $55 \%$ of DIP and $80 \%$ of $\mathrm{NH}_{4}{ }^{+}$could stem from tidal drainage at low tide

18 due to the tidal pump process (Fig. 8). This mechanism contributes for $15-47 \%$ of recycled

19 dissolved inorganic $\mathrm{N}$ into Arcachon Bay. The nutrient mass balance of the whole lagoon

20 includes also high sediment-water exchanges during immersion (De Wit, 1999). This part of $\mathrm{N}$

21 and P balance is not examined in this study. Welsh et al. (2000) showed that the sediment of

22 the Arcachon Bay was a net sink for $\mathrm{N}$ during immersion, especially because of high seagrass

23 uptake ( $\mathrm{N}$ and $\mathrm{P}$ ) during productive period. Nevertheless, the release of recycled nutrients

24 through tidal pumping is a perennial mechanism and almost constant whatsoever the season.

25 Thus, during periods of low nutrient inputs by freshwaters in summer, this process can support

26 a fast primary production of phytoplankton or macroalgae, such as Enteromorpha sp. and

27 Monostroma sp. 


\section{5. Conclusion}

Billerbeck et al. (2006a, b) showed that the underground drainage mechanism through

3 permeable sediments of tidal flat was an important nutrient source to coastal waters during ebb.

4 Actually, they explained that water infiltration supplied solutes and particles to sands during

5 inundation, which enhanced organic matter mineralization into sediment surface layer. The

6 authors demonstrated that the sand flat acted as a buffer system for nutrient according a

7 filtration cycle, due to the long residence time of pore-water. In Arcachon Bay, mineralization

8 processes are intense, because surface sediment on the intertidal flat consists mostly of muddy

9 and organic matter-rich sediment, thereby yielding pore-water with higher recycled nutrient

10 concentrations than pore-water derived from sands. At low tide, seeping by percolation,

11 diffusion or bioirrigation of these pore-waters feed a large creek web in whole lagoon. The

12 process is extremely important in controlling the nutrient levels of the lagoon, because the flux

13 out of the creek web integrates compounds of organic matter mineralization produced over a

14 wide area of tidal flat. According to rough estimations on one year, nutrient exports to the

15 pelagic system by this tidal pump provide about twice and 5 times more DIP and ammonia

16 inputs, respectively, in comparison with river freshwater fluxes. These findings suggest that

17 tidal flats contribute to enhance the eutrophication phenomena in the lagoon, especially in the

18 studied system, where continental $\mathrm{N}$ inputs are controlled by human activities (Rimmelin et al.,

19 1998; De Wit et al., 2005),. However, although these estimations seem to be very significant, it

20 is essential to remind that for a nutrient mass balance, differentiation between allochthonous

21 inputs and these recycled inputs is impossible. For that reason, both inputs cannot be added

22 together for the calculation of total available nutrient quantity in the whole lagoon. More

23 detailed studies are necessary to evaluate the residence time of pore-water within the intertidal

24 flat, in order to estimate the delaying time of mineralization product feedback to the ecosystem.

\section{Acknowledgements:}


1 The authors gratefully acknowledge Dr H. Etcheber for particulate carbon and sulphur analysis,

2 and S. Bujan for his assistance during sampling. We thank A. Mouret and D. Poirier who help

3 us on the study site or in laboratory. A. Carasco mostly contributed for laboratory analyses. We

4 also acknowledge M. Canton, the DIREN and IFREMER who provided additional data, J. Kerr

5 for help with the English version of this paper and the anonymous reviewers for scientific and

6 critical comments that have improved this paper. We express our gratitude to the municipality

7 of Lanton (Gironde, France). This study was supported by the French National Programme on

8 Coastal Environment (PNEC "Chantier Littoral Atlantique") and the ANR project PROTIDAL. 
Agosta, K., 1985. The effect of tidally induced changes in the creekbank water table on pore water chemistry. Estuarine, Coastal and Shelf Science 21, 389-400.

Anderson, L., 1979. Simultaneous spectrophotometric determination of nitrite and nitrate by flow injection analysis. Analytica Chemica Acta 110, 123-128.

Anschutz, P., Zhong, S., Sundby, B., Mucci, A. , Gobeil, C., 1998. Burial efficiency of phosphorus and the geochemistry of iron in continental margin sediments. Limnology and Oceanography 43 (1), 53-64.

Auby, I. , Labourg, P.-J., 1996. Seasonal dynamics of Zostera noltii hornem. In the Bay of Arcachon (France). Journal of Sea Research 35 (4), 269-277.

Auby, I., Manaud, F., Maurer, D. , Trut, G., 1994. Etude de la proliferation des algues vertes dans le Bassin d'Arcachon, IFREMER internal report, Arcachon, pp 275.

Berner, R.A., Westrich, J.T., 1985. Bioturbation and the early diagenesis of carbon and sulfur. American Journal of Science 285 (3), 193-206.

Billerbeck, M., Werner, U., Bosselmann, K., Walpersdorf, E. , Huettel, M., 2006a. Nutrient release from an exposed intertidal sand flat. Marine Ecology Progress Series 316, 3551.

Billerbeck, M., Werner, U., Polerecky, L., Walpersdorf, E., deBeer, D. , Huettel, M., 2006b. Surficial and deep pore water circulation governs spatials and temporal cales of nutrients recycling in intertidal sand flat sediment. Marine Ecology Progress Series 326, 61-76.

Blanchet, H., de Montaudouin, X., Chardy, P. , Bachelet, G., 2005. Structuring factors and recent changes in subtidal macrozoobenthic communities of a coastal lagoon, Arcachon Bay (France). Estuarine, Coastal and Shelf Science 64 (4), 561-576.

Blanchet, H., de Montaudouin, X., Lucas, A. , Chardy, P., 2004. Heterogeneity of macrozoobenthic assemblages within a Zostera noltii seagrass bed: diversity, abundance, biomass and structuring factors. Estuarine, Coastal and Shelf Science 61 (1), 111-123.

Charette, M.A., Sholkovitz, E.R. , Hansel, C.M., 2005. Trace element cycling in a subterranean estuary: Part 1. Geochemistry of the permeable sediments. Geochimica et Cosmochimica Acta 69 (8), 2095-2109.

Cottet, M., de Montaudouin, X., Blanchet, H. , Lebleu, P., 2007. Spartina anglica eradication experiment and in situ monitoring assess structuring strength of habitat complexity on marine macrofauna at high tidal level. Estuarine, Coastal and Shelf Science 71 (3-4), 629-640.

De Wit, R., Leibreich, J., Vernier, F., Delmas, F., Beuffe, H., Maison, P., Chossat, J.-C., Laplace-Treyture, C., Laplana, R. , Clave, V., 2005. Relationship between land-use in the agro-forestry system of les Landes, nitrogen loading to and risk of macro-algal blooming in the Bassin d'Arcachon coastal lagoon (SW France). Estuarine, Coastal and Shelf Science 62 (3), 453-465.

De Wit, R., Stal, L.J., Lomstein, B.A., Herbert, R.A., van Gemerden, H., Viaroli, P., Cecherelli, V.-U., Rodriguez-Valera, F., Bartoli, M., Giordani, G., 2001. ROBUST: The ROle of BUffering capacities in STabilising coastal lagoon ecosystems. Continental Shelf Research 21 (18-19), 2021-2041.

De Wit, R., 1999. The Role of Buffering capacities in STabilising coastal lagoon ecosystems, E.a.C.-. ELOISE, ENV4-CT96-0218, 2 volumes, pp 560.

Deborde, J., Anschutz, P., Chaillou, G., Etcheber, H., Commarieu, M.V., Lecroart, P. , Abril, G., 2007. The dynamics of phosphorus in turbid estuarine systems: Example of the Gironde estuary (France). Limnology and Oceanography 52 (2), 862-872.

Falcao, M. , Vale, C., 1995. Tidal flushing of ammonium from intertidal sediments of Ria Formosa, Portugal. Aquatic Ecology 29 (3-4), 239-244. 
Gassiat, L., 1989. Hydrodynamique et évolution sédimentaire d'un système lagune-flèche littorale: le Bassin d'Arcachon et la flèche du Cap Ferret, Thèse d'Etat, Université Bordeaux I, pp 340.

Grigg, N.J., Boudreau, B.P., Webster, I.T. , Ford, P.W., 2005. The nonlocal model of porewater irrigation: Limits to its equivalence with a cylinder diffusion model. Journal of Marine Research 63 (2), 437-455.

Hall, O.J. , Aller, R.C., 1992. Rapid, small volume, flow injection analysis for $\mathrm{SCO}_{2}$ and $\mathrm{NH}_{4}{ }^{+}$ in marine and freshwaters. Limnology and Oceanography 37, 1113-1119.

Huettel, M. , Rusch, A., 2000. Transport and degradation of phytoplankton in permeable sediment. Limnolology and Oceanography 45 (3), 534-549.

Huettel, M., Ziebis, W. , Forster, S., 1996. Flow-induced uptake of particulate matter in permeable sediments. Limnology and Oceanography 41 (2), 309-322.

Huettel, M., Ziebis, W., Forster, S. , Luther III, G.W., 1998. Advective Transport Affecting Metal and Nutrient Distributions and Interfacial Fluxes in Permeable Sediments. Geochimica et Cosmochimica Acta 62 (4), 613-631.

Jahnke, R.A., Alexander, C.R. , Kostka, J.E., 2003. Advective pore water input of nutrients to the Satilla River Estuary, Georgia, USA. Estuarine, Coastal and Shelf Science 56 (3-4), 641-653.

Koretsky, C.M., Meile, C. , Van Cappellen, P., 2002. Quantifying bioirrigation using ecological parameters: A stochastic approach. Geochemical Transactions (3), 17-30.

Kostka, J.E. , Luther, I., George W., 1994. Partitioning and speciation of solid phase iron in saltmarsh sediments. Geochimica et Cosmochimica Acta 58 (7), 1701-1710.

Krom, M.D. , Berner, R.A., 1980. The diffusion coefficients of sulfate, ammonium, and phosphate ions in anoxic marine sediments, Long Island Sound. Limnology and Oceanography 25 (2), 327-337.

Kuwae, T., Kibe, E. , Nakamura, Y., 2003. Effect of emersion and immersion on the porewater nutrient dynamics of an intertidal sandflat in Tokyo Bay. Estuarine, Coastal and Shelf Science 57 (5-6), 929-940.

Lewis, B.L. et al., 2007. Short-term and interannual variability of redox-sensitive chemical parameters in hypoxic/anoxic bottom waters of the Chesapeake Bay. Marine Chemistry, 105(3-4), 296-308.

Meysman, F.J.R., Galaktionov, O.S., Gribsholt, B. , Middelburg, J.J., 2006. Bioirrigation in permeable sediments: Advective pore-water transport induced by burrow ventilation. Limnology and Oceanography 51 (1 I), 142-156.

Moore, W.S., 1999. The subterranean estuary: a reaction zone of ground water and sea water. Marine Chemistry 65 (1-2), 111-125.

Morin, J. , Morse, J.W., 1999. Ammonium release from resuspended sediments in the Laguna Madre estuary. Marine Chemistry 65 (1-2), 97-110.

Mortimer, R.J.G., Krom, M.D., Watson, P.G., Frickers, P.E., Davey, J.T. , Clifton, R.J., 1999. Sediment-Water Exchange of Nutrients in the Intertidal Zone of the Humber Estuary, UK. Marine Pollution Bulletin 37 (3-7), 261-279.

Mullin, J.B. , Riley, J.P., 1955. The spectrophotometric determination of silicate-silicon in natural waters with special reference to sea water. Analytica Chemica Acta 12 162-170.

Murphy, J. , Riley, J.P., 1962. A modified single solution method for determination of phosphate in natural waters. Analytica Chemica Acta 42, 31-36.

Nielsen, P., 1990. Tidal dynamics of the water table in beaches. Water Resour Res 26, 21272134.

Rimmelin, P., Dumon, J.-C., Maneux, E., GonCalves, A., 1998. Study of Annual and Seasonal Dissolved Inorganic Nitrogen Inputs into the Arcachon Lagoon, Atlantic Coast (France). Estuarine, Coastal and Shelf Science 47 (5), 649-659.

Rocha, C., 1998. Rhythmic ammonium regeneration and flushing in intertidal sediments of the Sado estuary. Limnology and Oceanography 43, 823-831. 
Rocha, C., Cabe ̃̃§adas, G. , Brogueira, M.J., 1995. On the importance of sediment-water exchange processes of ammonia to primary production in shallow areas of the Sado estuary (Portugal). Aquatic Ecology V29 (3), 265-273.

Rodier, J., 1976. L'analyse de l'eau, eaux naturelles, eaux résiduaires, eau de mer,, Dunod (Ed.). Paris, pp 364.

Rusch, A., Huettel, M. , Forster, S., 2000. Particulate Organic Matter in Permeable Marine Sands--Dynamics in Time and Depth. Estuarine, Coastal and Shelf Science 51 (4), 399414.

Sakamaki, T., Nishimura, O., Sudo, R., 2006. Tidal time-scale variation in nutrient flux across the sediment-water interface of an estuarine tidal flat. Estuarine, Coastal and Shelf Science 67 (4), 653-663.

Simmons, J.D.H., 1992. Importance of submarine ground-water discharge (SGDW) and seawater cycling to material flux across sediment/water interfaces in marine environments. Marine Ecology Progress Series 84 173-184.

Stookey, L.L., 1970. Ferrozine-A new spectrophotometric reagent for iron. Analytica Chemica Acta 42, 779-781.

Strickland, J.D.H. , Parsons, T.R., 1972. A practical handbook of seawater analysis. Fisheries Research Board of Canada Bulletin 167, 1-31.

Sundby, B., Gobeil, C., Silverberg, N. , Mucci, A., 1992. The phosphorus cycle in coastal marine sediments. Limnology and Oceanography 37, 1129-1145.

Touchette, B.W. , Burkholder, J.M., 2000. Review of nitrogen and phosphorus metabolism in seagrasses. Journal of Experimental Marine Biology and Ecology 250 (1-2), 133-167.

Wang, Y. , Van Cappellen, P., 1996. A multicomponent reactive transport model of early diagenesis: Application to redox cycling in coastal marine sediments. Geochimica et Cosmochimica Acta 60 (16), 2993-3014.

Welsh, D.T., Bartoli, M., Nizzoli, D., Castaldelli, G., Riou, S.A. , Viaroli, P., 2000. Denitrification, nitrogen fixation, community primary productivity and inorganic-N and oxygen fluxes in an intertidl Zostera noltii meadow. Marine Ecology Progress Series 208, 65-77. 


\section{Figure captions}

2 Figure 1: Map of Arcachon Bay (France). Location of the study site (black circle), biweekly

3 monitoring (black triangle), and tidal cycle sampling (black square). Grey areas indicate 4 intertidal flats.

6 Figure 2: Schematic representation of the studied site viewed from the continent toward the 7 lagoon. Locations of different water samples collected in the estuarine channel (black crosses), 8 in the major tidal creek web, and tidal pool (open dots), in the minor tidal creek (open square), 9 and sediment core samples (black dots). The aquiclude influences the free aquifer by fresh underground water inputs, which generate a mixing zone. It forms a decreasing salinity 11 gradient in sandy sediments. In the bed of creeks (called regionally "Estey"), a red sand zone 12 (dotted area) is observed at the level of underground water seeping.

14 Figure 3: Monthly averaged nutrient concentrations $(\mu \mathrm{M})$ of high tide water in Teychan 15 channel from December 2002 to January 2004: $\Sigma\left(\mathrm{NO}_{3}{ }^{-}+\mathrm{NO}_{2}{ }^{-}\right)(0) ; \mathrm{NH}_{4}{ }^{+}(\Delta) ; \mathrm{PO}_{4}{ }^{3-}(\square)$. Error 16 bars represent Deviation Standard ( $\mathrm{n}=4$ to 8$)$.

Figure 4: Solute concentrations of water samples collected at low tide from March 2005 to

19 September 2006 vs. salinity: $\mathrm{pH}, \mathrm{Fe}^{2+}(+)$; $\mathrm{O}_{2}$ saturation, $\mathrm{SO}_{4}{ }^{2-}(\square) ; \mathrm{PO}_{4}{ }^{3-}, \mathrm{NH}_{4}{ }^{+}(\times) ; \Sigma\left(\mathrm{NO}_{3}{ }^{-}+\right.$ $\left.20 \mathrm{NO}_{2}^{-}\right)(\diamond) ; \Sigma \mathrm{CO} 2(\bullet) ; \mathrm{H}_{4} \mathrm{SiO}_{4}, \mathrm{Mn}^{2+}(\circ)$. The grey areas represent the tidal creek water samples. 21 The other points refer to estuarine channel water samples. The encircled point represents the 22 minor tidal creek sample. The dotted lines represent the dilution line for nitrate or sulfate Full 23 data set of solute concentration values of these water samples is available in Appendix A. HT: High Tide; LT: Low Tide. 
1 Figure 6: Evolution of nutrient concentrations in the tidal creek at spring during a complete

2 tidal cycle (day-night).

3

4 Figure 7a: Vertical profiles of dissolved and particulate species of cores collected on the creek 5 edge in May 2005, July 2005 and January 2006. The core collected in January 2006 showed a

6 porosity and particulate carbon content different to the other cores, which was due to a higher

7 mean grain size.

8

9 Figure 7b: Vertical profiles of dissolved and particulate species of cores collected in the bed of 10 creek in May 2005, July 2005 and January 2006. From the surface to $4 \mathrm{~cm}$ depth, permeable 11 sediments were characterized by a red color corresponding to maxima of particulate iron 12 concentrations.

13

14 Figure 8: Schematic sediment-water exchange diagram in Arcachon Bay during ebb. Rainfall 15 and groundwater data come from literature and personal communications. These values are 16 given for an arithmetic mean between inputs during dry and wet period, and between those 17 from forest wells and urban wells. Tidal pump inputs are calculated for a mean minimal tidal 18 pumping of $1 \mathrm{~h} 30 \mathrm{~min}$ per tidal cycle. Seawater concentration data come from a biweekly 19 monitoring on surface waters (Fig. 3). 


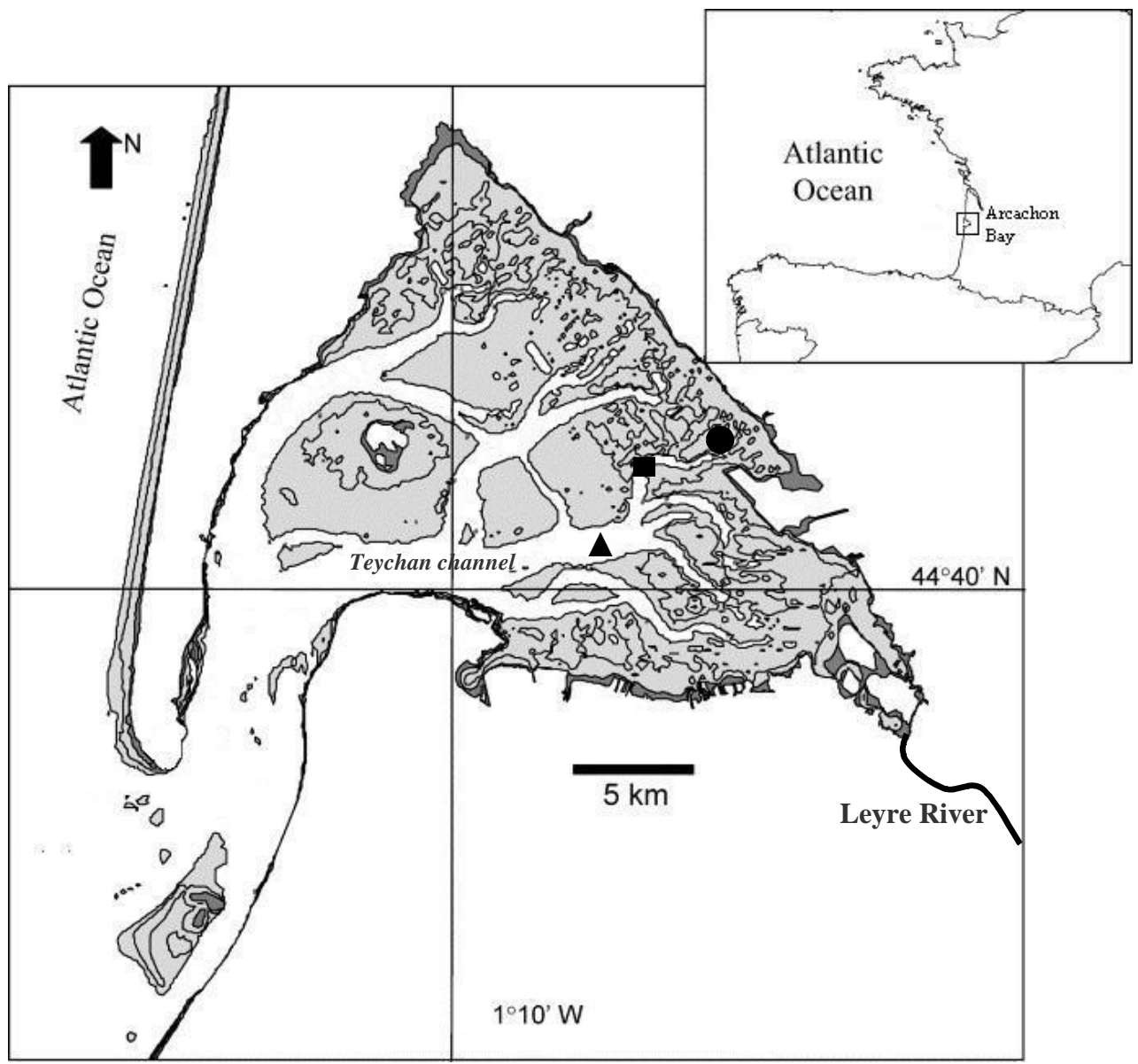



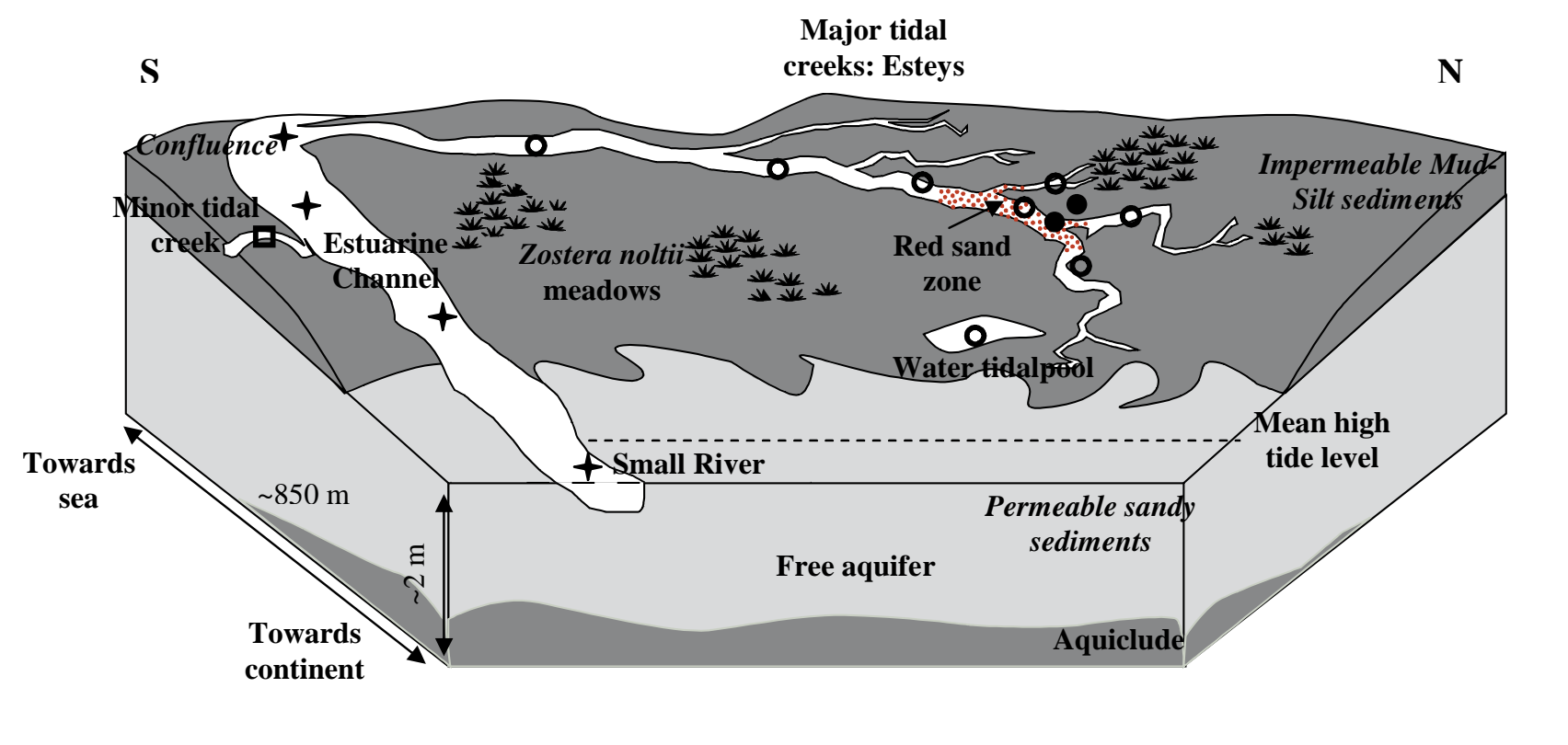
contin 


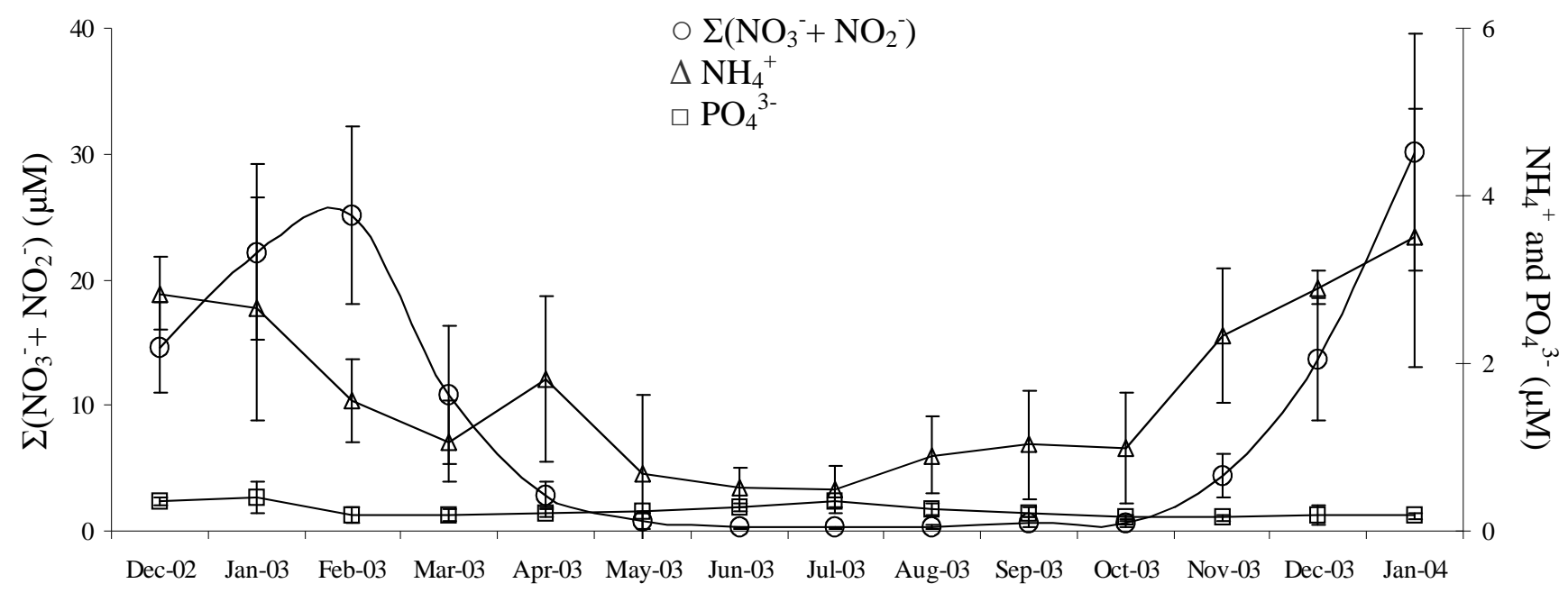



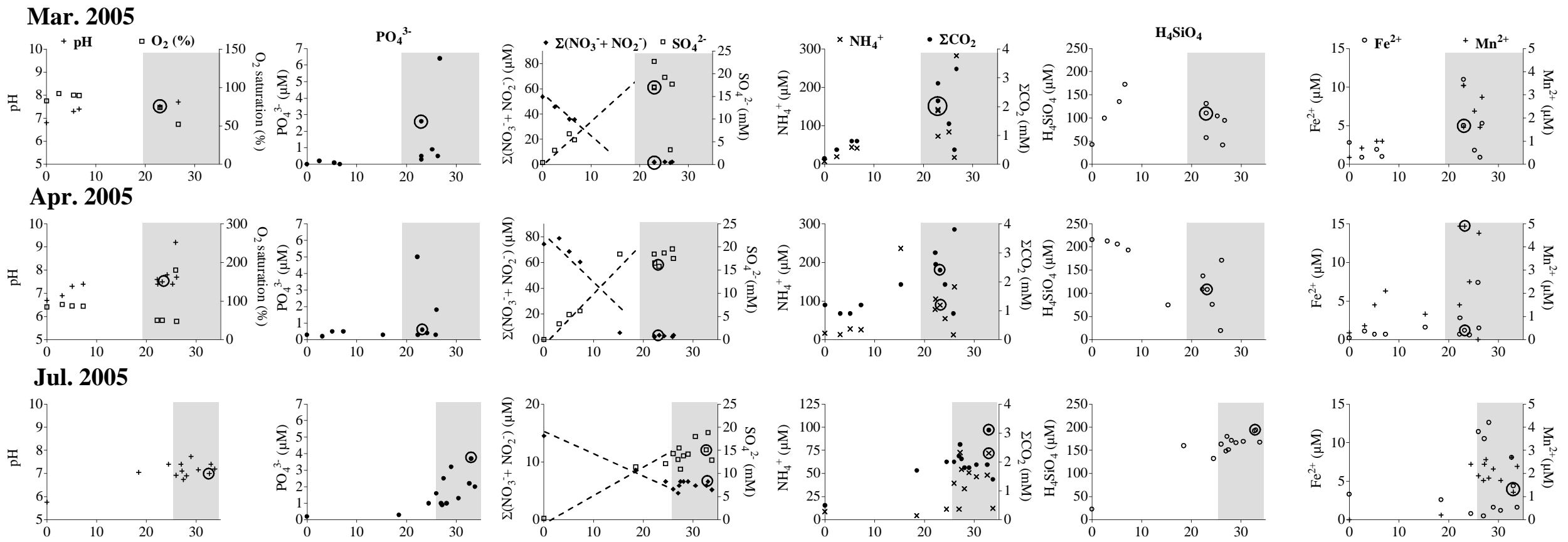

\section{Nov. 2005}
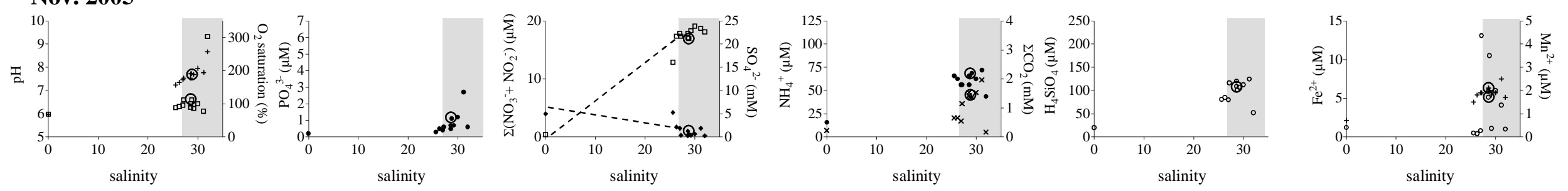


\section{J an. 2006}
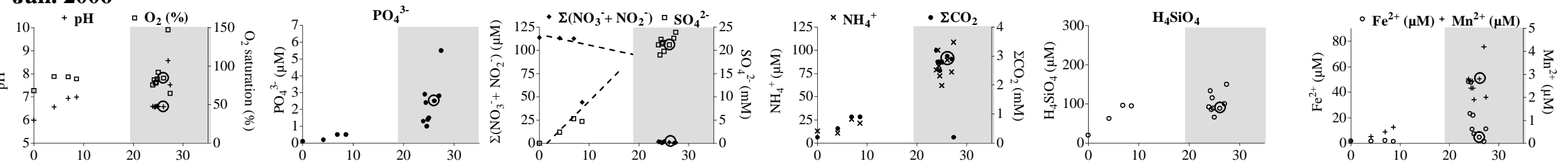

\section{Mar. 2006}
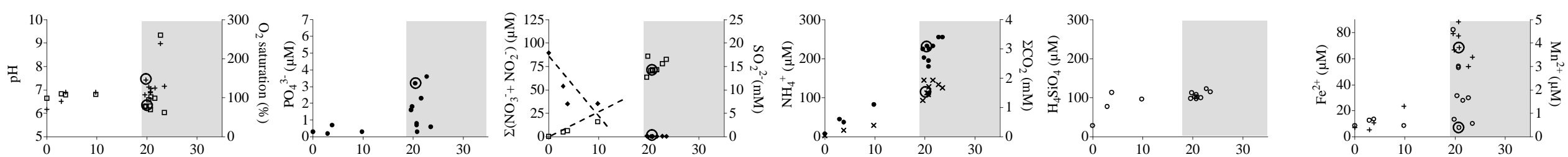

\section{M ay 2006}
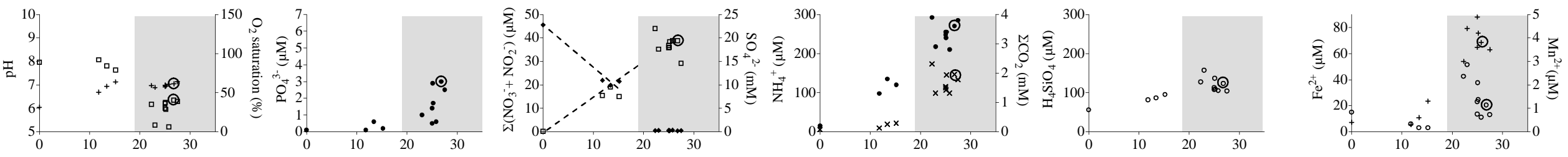

\section{J ul. 2006}
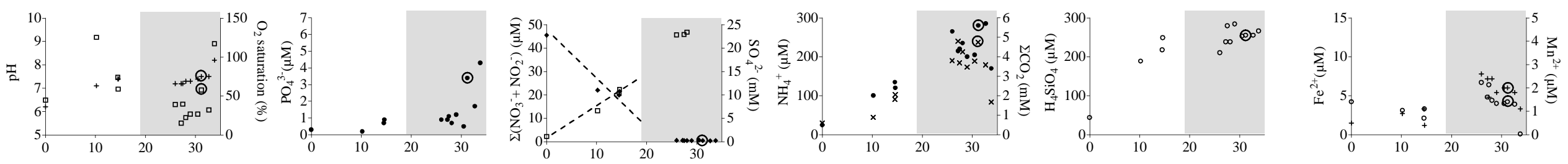

\section{Sep. 2006}
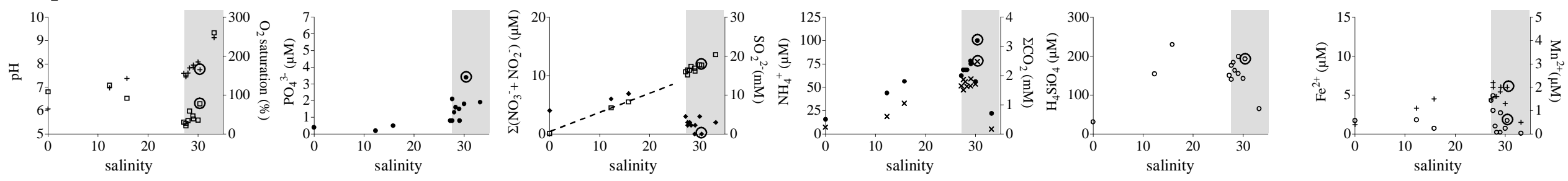
Figure 5

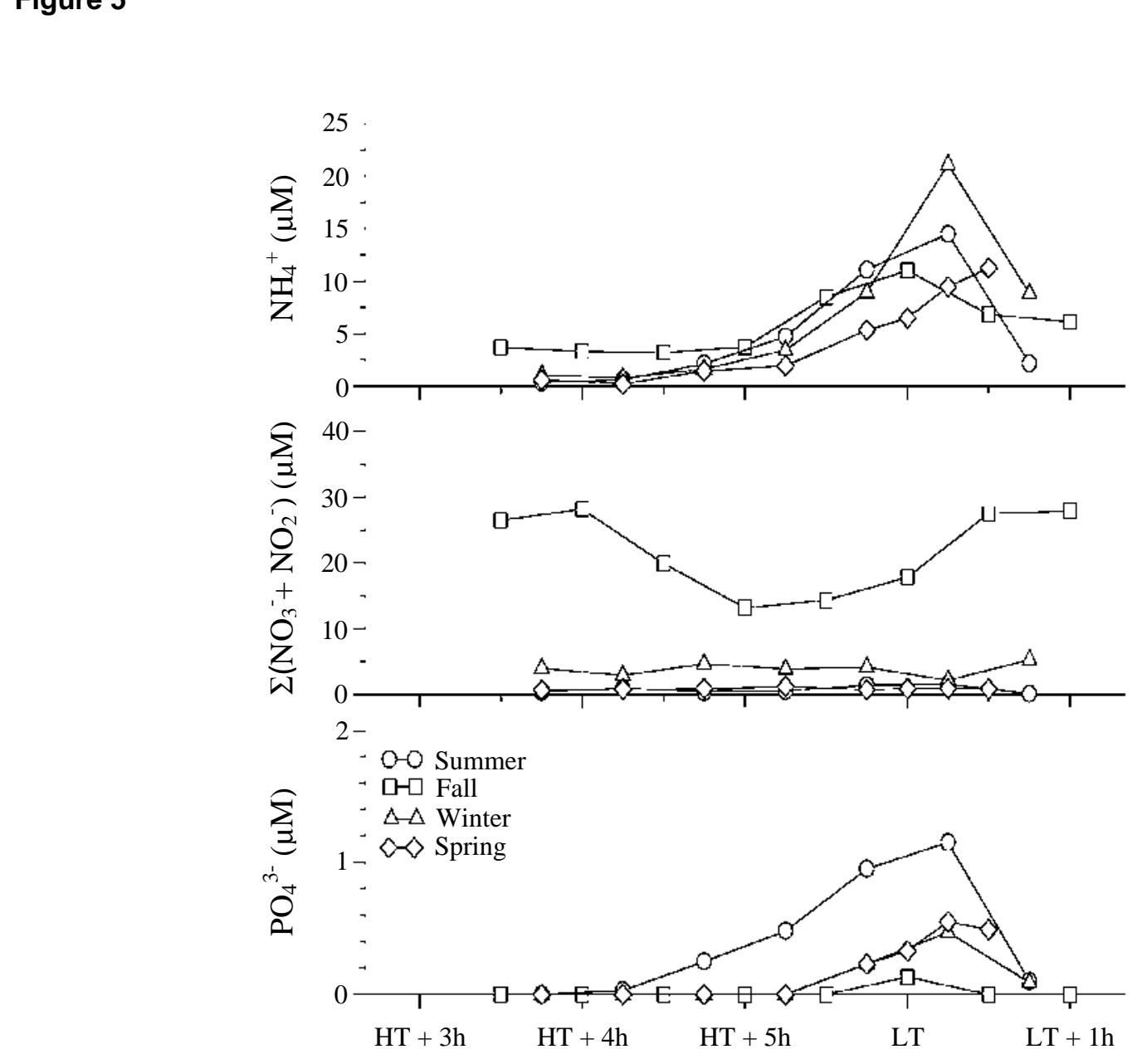

$\sum_{3} 40-$

$\overbrace{}^{2} 30$ -

Z $20-$

$0^{m} 10-$

屯 0

2-

- o- Summer

$\sum_{3} \quad \Delta-\Delta$ W Winter

$1-\leadsto$ Spring

$\overbrace{}^{m}$

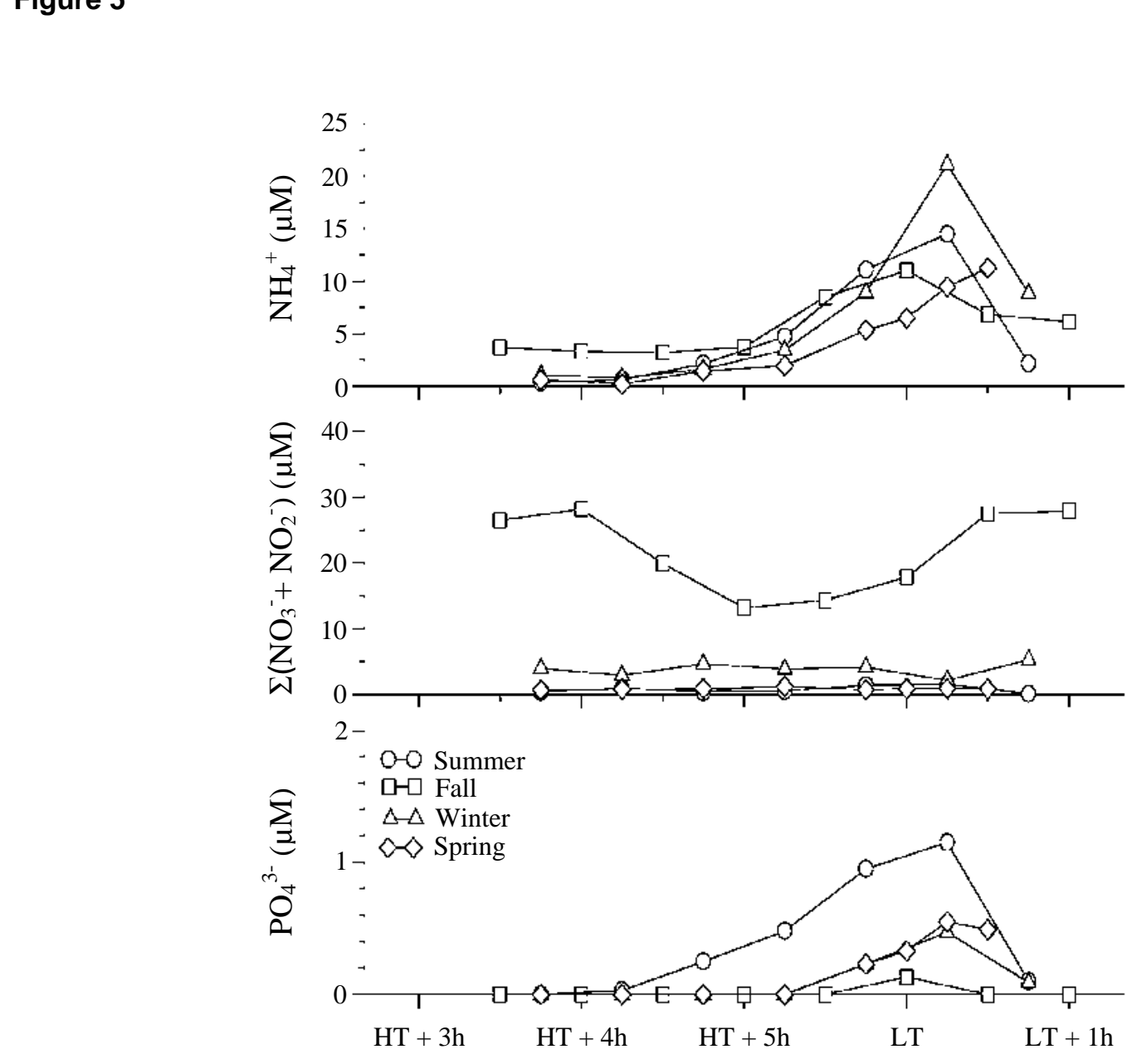

$H T+3 h$

$\mathrm{HT}+4 \mathrm{~h}$

$\mathrm{LT}+1 \mathrm{~h}$ 


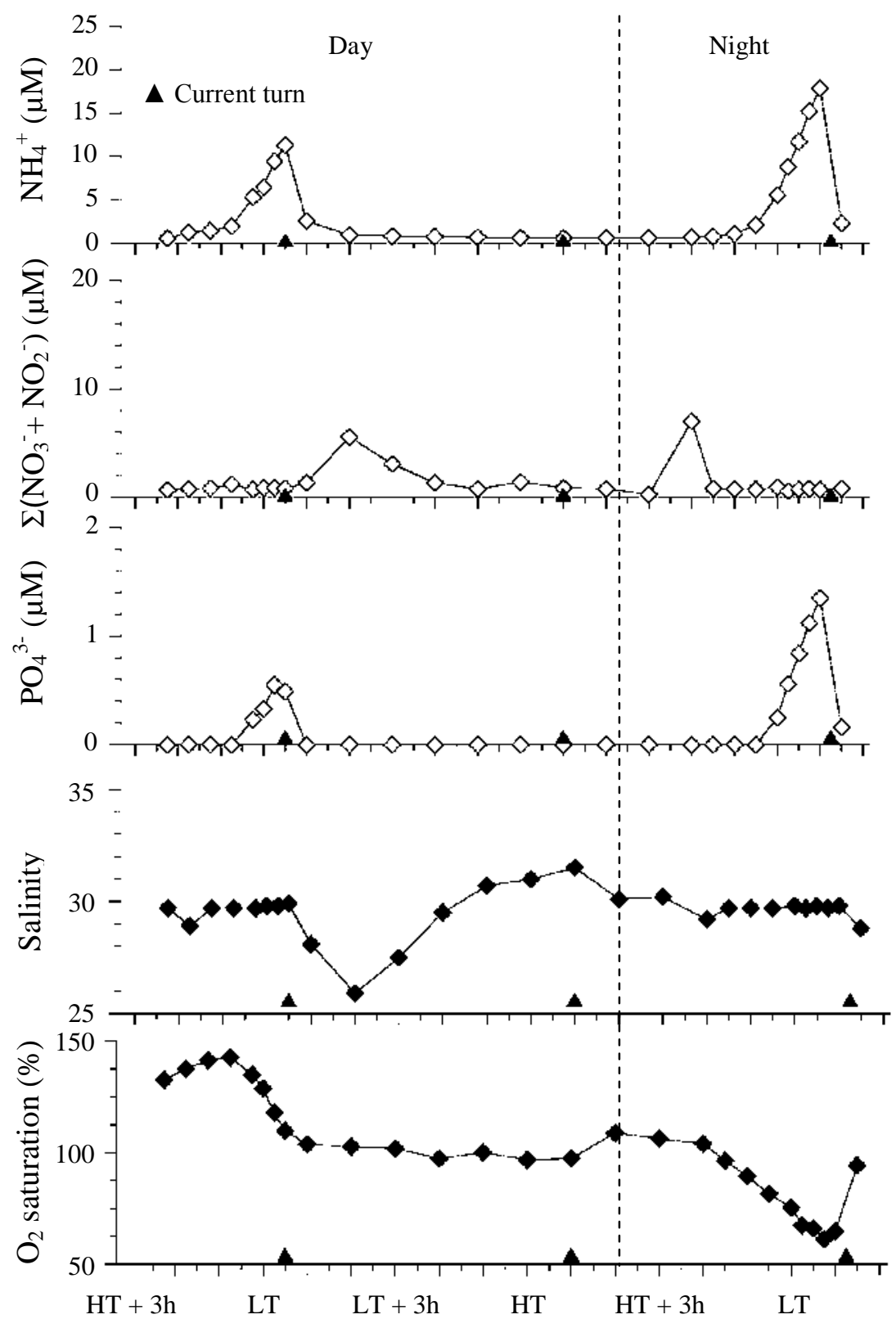


$\circ$ Salinity $\quad \circ \Sigma\left(\mathrm{NO}_{3}^{-}+\mathrm{NO}_{2}^{-}\right)(\mu \mathrm{M})$

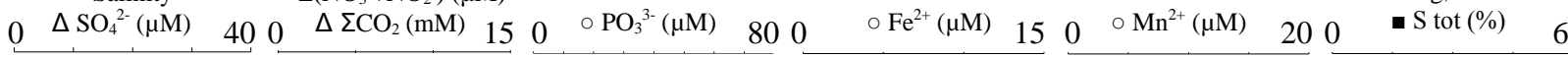

$\circ \mathrm{C}$ org, $\Delta \mathrm{C}$ tot

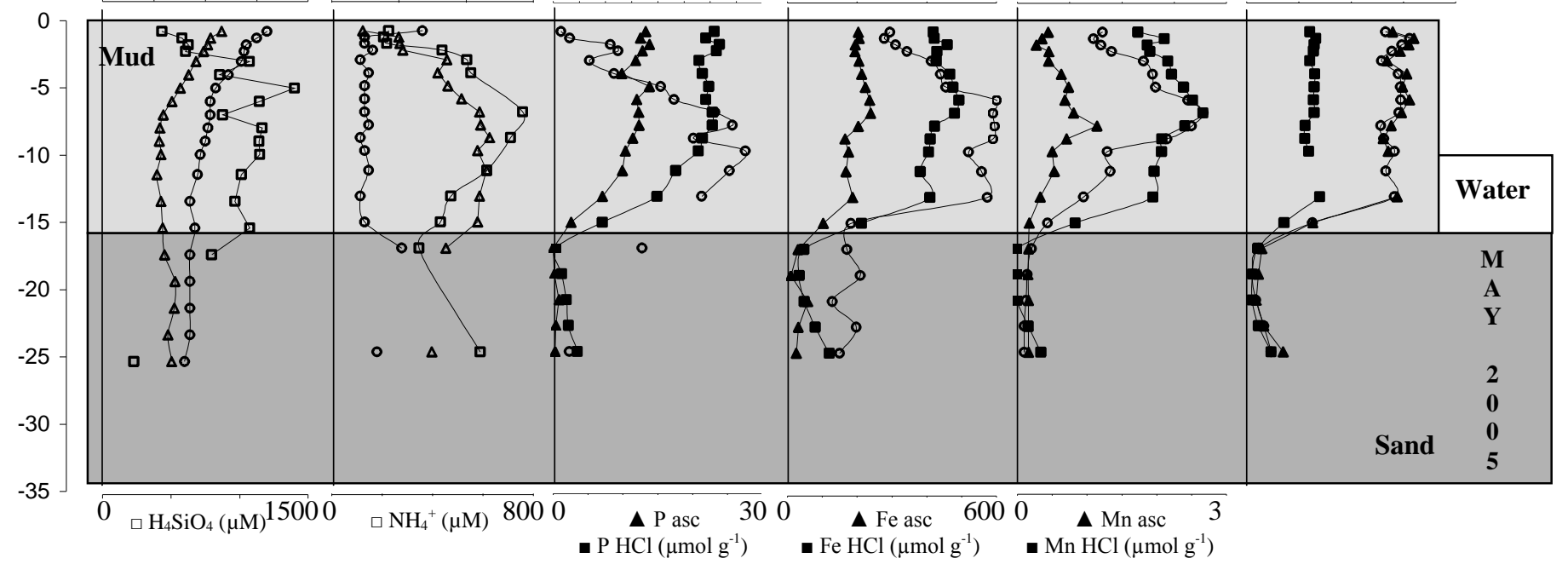

- Salinity

$0 \Delta \mathrm{SO}_{4}{ }^{2-}(\mu \mathrm{M}) \quad 400 \quad \Delta \Sigma \mathrm{CO}_{2}(\mathrm{mM}) \quad 150 \quad \circ \mathrm{PO}_{3}{ }^{3-}(\mu \mathrm{M}) \quad 100-\circ \mathrm{Fe}^{2+}(\mu \mathrm{M}) \quad 150 \quad \circ \mathrm{Mn}^{2+}(\mu \mathrm{M}) \quad 30$

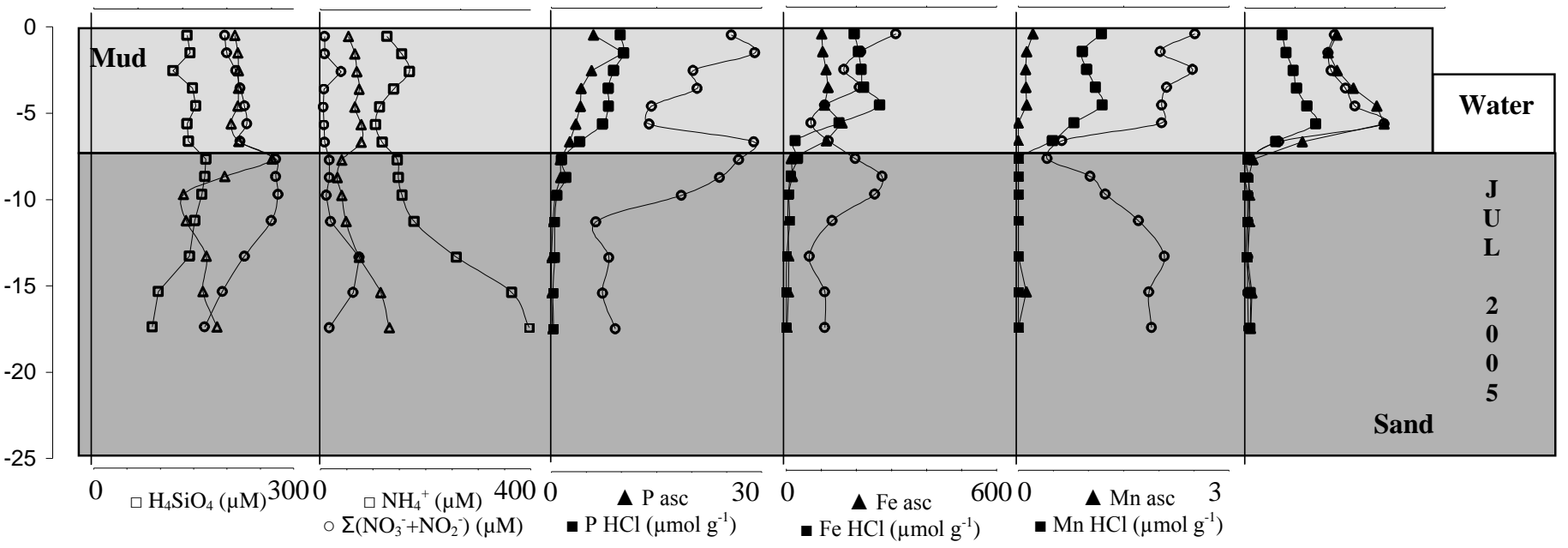

$\circ$ Salinity

$0 . \triangle \mathrm{S}^{2-}(\mathrm{m})$

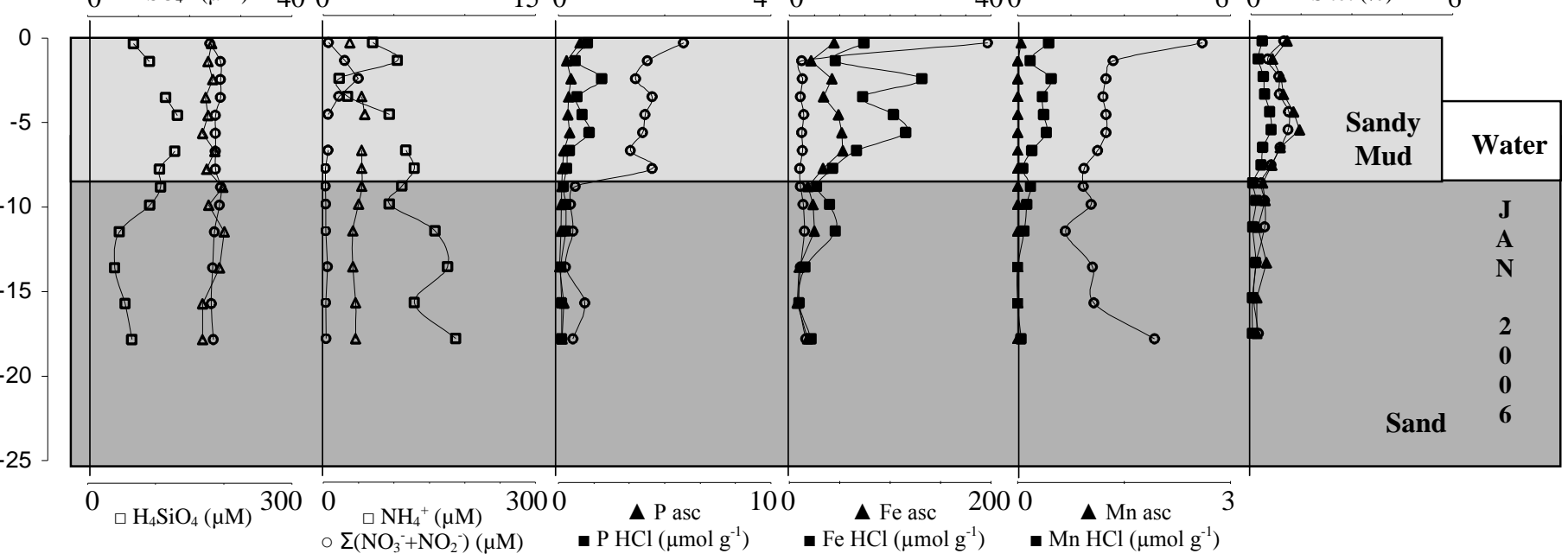



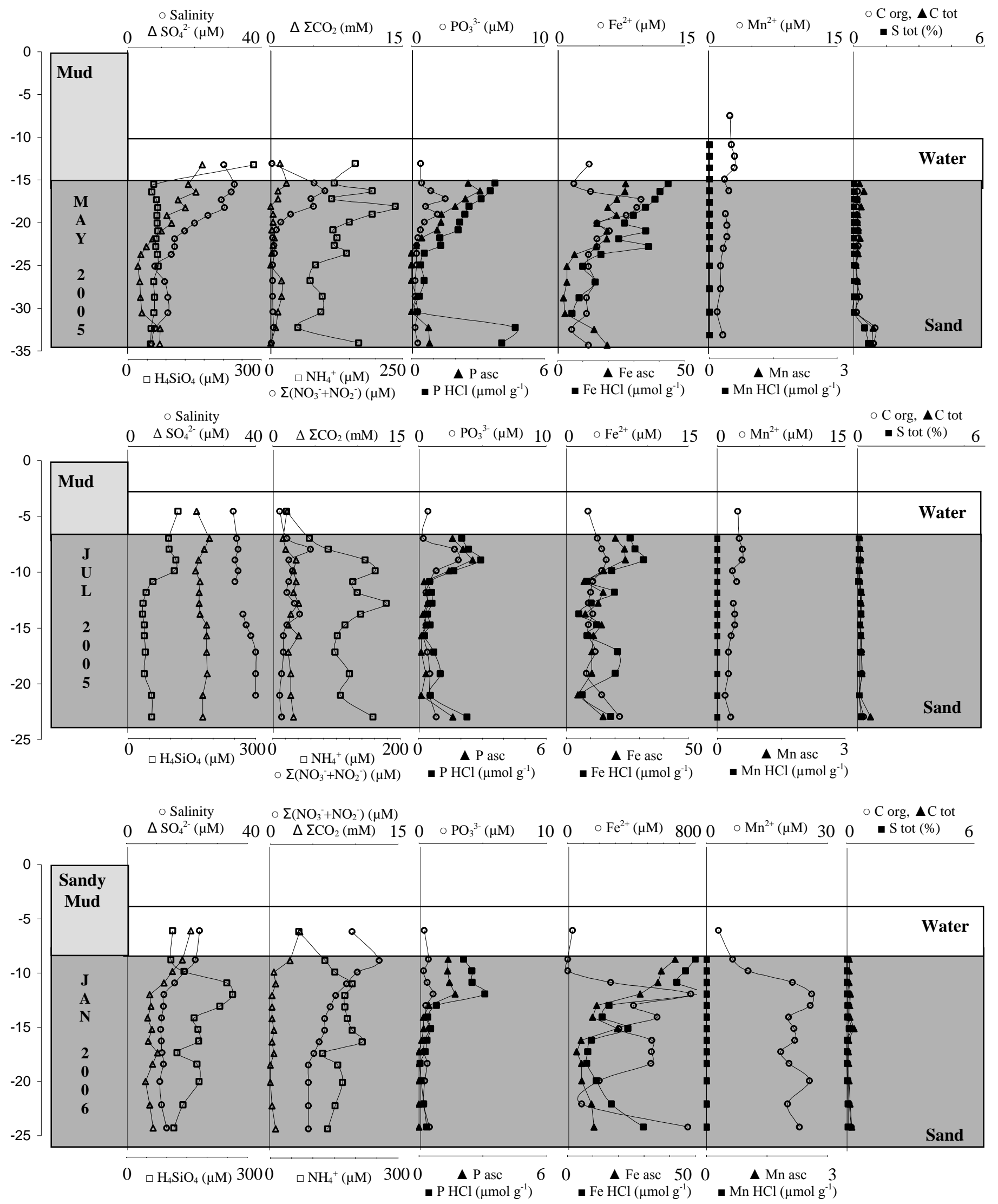


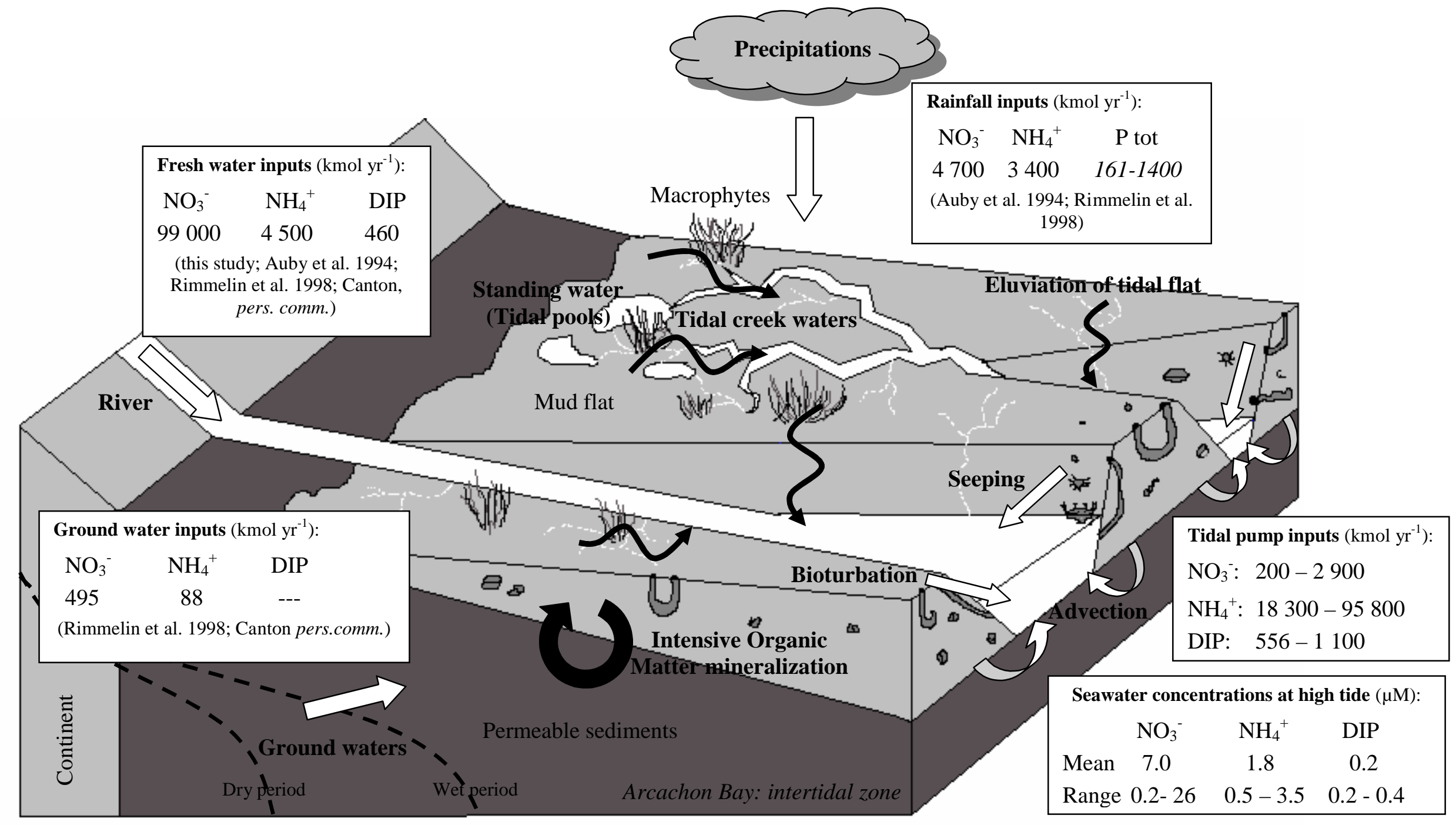


Table 1. Sampling procedures implemented during field work.

\begin{tabular}{|c|c|c|c|c|}
\hline Sampling date & Sampling station & Sample & Frequency & Geochimical analysis \\
\hline Summer 1992 & 6-h tidal cycle & Surface water & $15-30 \mathrm{~min}$ & $\Sigma \mathrm{NO}_{3}^{-}, \mathrm{NH}_{4}^{+}, \mathrm{PO}_{4}^{3-}$ \\
\hline Fall 1992 & 6-h tidal cycle & Surface water & $15-30 \mathrm{~min}$ & $\Sigma \mathrm{NO}_{3}^{-}, \mathrm{NH}_{4}^{+}, \mathrm{PO}_{4}^{3-}$ \\
\hline W inter 1993 & 6-h tidal cycle & Surface water & $15-30 \mathrm{~min}$ & $\Sigma \mathrm{NO}_{3}{ }^{-}, \mathrm{NH}_{4}^{+}, \mathrm{PO}_{4}^{3-}$ \\
\hline Spring 1993 & 24-h tidal cycle & Surface water & $15-30 \mathrm{~min}$ & $\Sigma \mathrm{NO}_{3}^{-}, \mathrm{NH}_{4}^{+}, \mathrm{PO}_{4}^{3-}$ \\
\hline Dec. 2002 to Jan. 2004 & $\begin{array}{l}\text { Lagoon water } \\
\text { (high tide) }\end{array}$ & Surface water & biweekly & $\Sigma \mathrm{NO}_{3}{ }^{-}, \mathrm{NH}_{4}{ }^{+}, \mathrm{PO}_{4}{ }^{3-}$ \\
\hline M ar. 2005 to Sep. 2006 & Freshwater river & Surface water & bimonthly & $\begin{array}{l}\mathrm{\Sigma NO}_{3}^{-}, \mathrm{NH}_{4}^{+}, \mathrm{PO}_{4}{ }^{3-}, \mathrm{H}_{4} \mathrm{SiO}_{4} \\
\mathrm{SO}_{4}^{2-}, \Sigma \mathrm{CO}_{2}, \mathrm{Fe}^{2+}, \mathrm{M} \mathrm{n}^{2+}\end{array}$ \\
\hline M ar. 2005 to Sep. 2006 & $\begin{array}{l}\text { Estuarine channel } \\
\text { (ebb) }\end{array}$ & Surface water & bimonthly & $\begin{array}{l}\Sigma \mathrm{NO}_{3}^{-}, \mathrm{NH}_{4}^{+}, \mathrm{PO}_{4}{ }^{3-}, \mathrm{H}_{4} \mathrm{SiO}_{4} \\
\mathrm{SO}_{4}^{2-}, \Sigma \mathrm{CO}_{2}, \mathrm{Fe}^{2+}, \mathrm{M} \mathrm{n}^{2+}\end{array}$ \\
\hline M ar. 2005 to Sep. 2006 & $\begin{array}{l}\text { Tidal creeks } \\
\quad(e b b)\end{array}$ & Surface water & bimonthly & $\begin{array}{c}\mathrm{NNO}_{3}, \mathrm{NH}_{4}{ }^{+}, \mathrm{PO}_{4}{ }^{3-}, \mathrm{H}_{4} \mathrm{SiO}_{4}, \\
\mathrm{SO}_{4}{ }^{2-}, \Sigma \mathrm{CO}_{2}, \mathrm{Fe}^{2+}, \mathrm{Mn} \mathrm{n}^{2+}\end{array}$ \\
\hline M ay 2005 & Tidal mudflat & $\begin{array}{l}\text { Porewater \& } \\
\text { particulate } \\
\text { fraction }\end{array}$ & & $\begin{array}{l}\Sigma \mathrm{NO}_{3}^{-}, \mathrm{NH}_{4}{ }^{+}, \mathrm{PO}_{4}{ }^{3-}, \mathrm{H}_{4} \mathrm{SiO}_{4} \\
\mathrm{SO}_{4}^{2-}, \Sigma \mathrm{CO}_{2}, \mathrm{Fe}^{2+}, \mathrm{M} \mathrm{n}^{2+} \\
\text { A scorbate and } \mathrm{HCl} \\
\text { extractable } \mathrm{Fe}, \mathrm{Mn} \text { and } \mathrm{P} ; \\
\quad \text { Corg, Ctot, Stot }\end{array}$ \\
\hline July 2005 & Tidal mudflat & $\begin{array}{l}\text { Porewater \& } \\
\text { particulate } \\
\text { fraction }\end{array}$ & & $\begin{array}{c}\mathrm{SNO}_{3}, \mathrm{NH}_{4}^{+}, \mathrm{PO}_{4}{ }^{3-}, \mathrm{H}_{4} \mathrm{SiO}_{4} \\
\mathrm{SO}_{4}^{2-}, \Sigma \mathrm{CO}_{2}, \mathrm{Fe}^{2+}, \mathrm{M} \mathrm{n}^{2+} ; \\
\text { A scorbate and } \mathrm{HCl} \\
\text { extractable } \mathrm{Fe}, \mathrm{Mn} \text { and } \mathrm{P} ; \\
\text { Corg, Ctot, Stot }\end{array}$ \\
\hline J anuary 2006 & Tidal mudflat & $\begin{array}{l}\text { Porewater \& } \\
\text { particulate } \\
\text { fraction }\end{array}$ & & $\begin{array}{c}\mathrm{\Sigma NO}_{3}, \mathrm{NH}_{4}{ }_{4}, \mathrm{PO}_{4}{ }^{3-}, \mathrm{H}_{4} \mathrm{SiO}_{4}, \\
\mathrm{SO}_{4}^{2-}, \Sigma \mathrm{CO}_{2}, \mathrm{Fe}^{2+}, \mathrm{M} \mathrm{n}^{2+} ; \\
\text { A scorbate and } \mathrm{HCl} \\
\text { extractable } \mathrm{Fe}, \mathrm{Mn} \text { and } \mathrm{P} ; \\
\text { Corg, } \mathrm{C} \text { tot, Stot }\end{array}$ \\
\hline
\end{tabular}


Table 2. Water sample characteristics: temperature, $\mathrm{O}_{2}$ saturation, $\mathrm{pH}$ and salinity. For estuarine and major tidal creek samples, an average value is indicated with standard deviation in parentheses ( $n=5$ to 8 ).

\begin{tabular}{|c|c|c|c|c|}
\hline Site and Date & $\mathrm{T}\left({ }^{\circ} \mathrm{C}\right)$ & $\mathrm{O}_{2}(\%)$ & $\mathrm{pH}$ & Salinity \\
\hline Mar. 2005 & & & & \\
\hline River & 13.0 & 82.4 & 6.8 & 0.0 \\
\hline Estuarine channel & $18.4(2.2)$ & $85.0(5.2)$ & $7.4(0.6)$ & $<6.6$ \\
\hline M ajor tidal creek & $24.1(2.3)$ & $75.0(9.8)$ & $7.5(0.1)$ & $25.0(1.7)$ \\
\hline M inor tidal creek & 23.1 & 74.0 & 7.5 & 23.0 \\
\hline $\begin{array}{l}\text { Tidalpool } \\
\quad \text { Apr. } 2005\end{array}$ & - & - & - & - \\
\hline River & 15.1 & 84.8 & 6.7 & 0.0 \\
\hline Estuarine channel & $20.0(1.7)$ & $87.0(6.4)$ & $7.3(0.3)$ & $<7.3$ \\
\hline M ajor tidal creek & $25.0(4.1)$ & $50.0(7.4)$ & $7.5(0.2)$ & $22.2(1.6)$ \\
\hline M inor tidal creek & 25.8 & 47.2 & 7.7 & 24.2 \\
\hline $\begin{array}{l}\text { Tidalpool } \\
\qquad \text { J ul. } 2005\end{array}$ & 25.2 & 180.0 & 9.2 & 25.9 \\
\hline River & 17.3 & - & 5.8 & 0.0 \\
\hline Estuarine channel & $27.5(4.4)$ & - & $7.4(0.2)$ & $<27$ \\
\hline M ajor tidal creek & $31.1(2.6)$ & - & $6.9(0.3)$ & $29.9(2.6)$ \\
\hline M inor tidal creek & 30.0 & - & 7.4 & 33.0 \\
\hline $\begin{array}{l}\text { Tidalpool } \\
\quad \text { Nov. } 2005\end{array}$ & 30.2 & - & 7.2 & 33.8 \\
\hline River & 14.6 & 68.0 & 6.0 & 0.0 \\
\hline Estuarine channel & $16.8(0.3)$ & $91.8(0.2)$ & $7.3(0.1)$ & $<26.5$ \\
\hline M ajor tidal creek & $20.0(1.1)$ & $100.1(10.8)$ & $7.8(0.1)$ & $29.2(1.3)$ \\
\hline M inor tidal creek & 18.4 & 86.1 & 7.7 & 28.6 \\
\hline $\begin{array}{l}\text { Tidalpool } \\
\qquad \text { J an. } 2006\end{array}$ & 20.2 & 302.6 & 8.7 & 32.0 \\
\hline River & 9.2 & 68.0 & 6.0 & 0.0 \\
\hline Estuarine channel & $8.3(0.2)$ & $86.2(4.7)$ & $6.9(0.2)$ & $<8.6$ \\
\hline M ajor tidal creek & $7.5(0.2)$ & $80.1(7.2)$ & $6.6(0.2)$ & $25.0(1.2)$ \\
\hline M inor tidal creek & 7.8 & 64.4 & 7.5 & 27.4 \\
\hline $\begin{array}{l}\text { Tidalpool } \\
\qquad \text { Mar. } 2006\end{array}$ & 7.5 & 147.0 & 8.6 & 27.0 \\
\hline River & 13.6 & 107.0 & 6.9 & 0.0 \\
\hline Estuarine channel & $17.0(2.1)$ & $100.0(2.1)$ & $7.1(0.2)$ & $<23.5$ \\
\hline M ajor tidal creek & $24.5(1.4)$ & $85.0(3.1)$ & $7.4(0.2)$ & $19.8(1.2)$ \\
\hline M inor tidal creek & 24.3 & 78.5 & 6.9 & 20.5 \\
\hline $\begin{array}{l}\text { Tidalpool } \\
\qquad \text { May } 2006\end{array}$ & 25.0 & 260.0 & 8.9 & 22.7 \\
\hline River & 12.0 & 89.0 & 6.0 & 0.0 \\
\hline Estuarine channel & $20.0(2.0)$ & $86.0(1.8)$ & $7.0(0.2)$ & $<15.2$ \\
\hline M ajor tidal creek & $28.7(0.9)$ & $32.0(2.7)$ & $7.1(0.2)$ & $28.5(1.3)$ \\
\hline M inor tidal creek & 26.6 & 38.5 & 6.9 & 27.5 \\
\hline $\begin{array}{l}\text { Tidalpool } \\
\qquad \text { Jul. } 2006\end{array}$ & 31.1 & - & - & 22.3 \\
\hline River & 16.4 & 44.5 & 6.2 & 0.0 \\
\hline Estuarine channel & $29.1(2.2)$ & $100.0(1.9)$ & $7.2(0.2)$ & $<14.6$ \\
\hline M ajor tidal creek & $31.8(0.8)$ & $57.4(7.9)$ & $7.5(0.2)$ & $29.0(2.3)$ \\
\hline M inor tidal creek & 32.4 & 32.0 & 7.3 & 31.2 \\
\hline $\begin{array}{l}\text { Tidalpool } \\
\quad \text { Sep. } 2006\end{array}$ & 33.2 & 117.0 & 8.2 & 33.8 \\
\hline River & 22.3 & 108.0 & 6.1 & 0.0 \\
\hline Estuarine channel & $23.7(1.2)$ & $97.0(1.3)$ & $7.5(0.2)$ & $<28.3$ \\
\hline M ajor tidal creek & $25.5(0.8)$ & $32.0(2.4)$ & $7.8(0.1)$ & $28.5(1.2)$ \\
\hline M inor tidal creek & 24.9 & 46.1 & 7.9 & 30.4 \\
\hline Tidalpool & 27.3 & 260.0 & 9.1 & 33.2 \\
\hline
\end{tabular}


A ppendix A . Full data set of solute concentration values of the water samples collected at low tide from M arch 2005 to September 2006. This data set is an additional section of Figure 4.

\begin{tabular}{|c|c|c|c|c|c|c|c|c|c|c|}
\hline $\begin{array}{l}\text { Sampling } \\
\text { date }\end{array}$ & $\begin{array}{l}\text { Sample } \\
\text { station }\end{array}$ & Salinity & $\begin{array}{l}\mathrm{PO}_{4}{ }^{3-} \\
(\mu \mathrm{M})\end{array}$ & $\begin{array}{c}\Sigma\left(\mathrm{NO}_{2}^{-}+\mathrm{NO}_{3}{ }^{-}\right) \\
(\mu \mathrm{M})\end{array}$ & $\begin{array}{l}\mathrm{NH}_{4}^{+} \\
(\mu \mathrm{M})\end{array}$ & $\begin{array}{c}\mathrm{H}_{4} \mathrm{SiO}_{4} \\
(\mu \mathrm{M})\end{array}$ & $\begin{array}{l}\mathrm{SO}_{4}{ }^{2-} \\
(\mathrm{mM})\end{array}$ & $\begin{array}{l}\Sigma \mathrm{CO}_{2} \\
(\mathrm{mM})\end{array}$ & $\begin{array}{l}\mathrm{Fe}^{2+} \\
(\mu \mathrm{M})\end{array}$ & $\begin{array}{l}M^{2+} \\
(\mu M)\end{array}$ \\
\hline \multicolumn{11}{|l|}{ M ar. 2005} \\
\hline \multirow{4}{*}{\multicolumn{2}{|c|}{ Estuarine channel }} & 0.0 & 0.0 & 53.8 & 7.2 & 42.6 & 0.4 & 0.2 & 2.8 & 0.3 \\
\hline & & 2.5 & 0.2 & 45.7 & 19.3 & 99.2 & 3.1 & 0.5 & 0.9 & 0.7 \\
\hline & & 5.5 & 0.1 & 36.0 & 43.7 & 135.1 & 6.7 & 0.8 & 1.9 & 1.0 \\
\hline & & 6.6 & 0.0 & 35.7 & 41.5 & 172.1 & 5.4 & 0.8 & 1.0 & 1.0 \\
\hline \multirow{5}{*}{\multicolumn{2}{|c|}{ Tidal creeks }} & 26.7 & 6.4 & 1.9 & 282.0 & 94.2 & 17.7 & 3.3 & 5.3 & 2.9 \\
\hline & & 23.0 & 0.3 & 1.6 & 138.8 & 130.6 & 16.9 & 2.2 & 5.0 & 3.4 \\
\hline & & 23.0 & 0.5 & 1.9 & 142.2 & 110.4 & 17.1 & 2.8 & 11.0 & 3.4 \\
\hline & & 23.0 & 2.6 & 1.5 & 72.3 & 57.2 & 22.7 & 2.2 & 5.0 & 1.6 \\
\hline & & 25.2 & 0.9 & 1.9 & 83.7 & 104.3 & 19.2 & 1.4 & 1.8 & 2.3 \\
\hline & Tidal pool & 26.3 & 0.5 & 1.3 & 17.2 & 41.5 & 3.2 & 0.5 & 0.9 & 1.6 \\
\hline \multicolumn{11}{|l|}{ Apr. 2005} \\
\hline \multirow{4}{*}{\multicolumn{2}{|c|}{ Estuarine channel }} & 0.0 & 0.3 & 74.3 & 16.4 & 215.9 & 0.0 & 1.2 & 0.2 & 0.3 \\
\hline & & 3.1 & 0.2 & 78.8 & 13.3 & 212.8 & 3.4 & 0.9 & 1.1 & 0.6 \\
\hline & & 5.1 & 0.5 & 68.5 & 27.7 & 206.1 & 5.4 & 0.9 & 0.7 & 1.5 \\
\hline & & 7.3 & 0.5 & 60.4 & 25.7 & 193.3 & 6.2 & 1.2 & 0.7 & 2.1 \\
\hline \multirow{6}{*}{\multicolumn{2}{|c|}{ Tidal creeks }} & 26.1 & 1.8 & 3.4 & 136.6 & 171.2 & 17.5 & 3.8 & 1.5 & 4.6 \\
\hline & & 23.2 & 0.6 & 3.4 & 89.3 & 108.2 & 15.8 & 2.4 & 1.2 & 4.9 \\
\hline & & 22.2 & 5.0 & 2.6 & 78.0 & 108.7 & 18.5 & 3.0 & 0.7 & 1.5 \\
\hline & & 22.3 & 0.3 & 2.3 & 104.7 & 137.4 & 16.5 & 2.6 & 2.8 & 4.9 \\
\hline & & 24.2 & 0.4 & 2.9 & 54.4 & 75.9 & 18.7 & 1.9 & 0.6 & 2.5 \\
\hline & & 25.3 & 0.3 & 5.4 & 236.1 & 74.5 & 18.5 & 1.9 & 1.6 & 1.1 \\
\hline & Tidal pool & 25.9 & 0.3 & 2.3 & 12.3 & 19.0 & 19.6 & 0.9 & 7.4 & 0.0 \\
\hline \multicolumn{11}{|l|}{ J ul. 2005} \\
\hline \multirow{4}{*}{\multicolumn{2}{|c|}{ Estuarine channel }} & 0.0 & 0.2 & 14.5 & 8.8 & 23.2 & 0.3 & 0.5 & 3.3 & 0.0 \\
\hline & & 18.5 & 0.3 & 8.6 & 4.4 & 159.7 & 11.4 & 1.7 & 2.6 & 0.2 \\
\hline & & 24.5 & 1.0 & 6.6 & 11.4 & 131.7 & 12.1 & 2.0 & 0.8 & 2.4 \\
\hline & & 27.0 & 1.0 & 4.6 & 11.4 & 148.2 & 13.0 & 2.2 & 0.5 & 1.7 \\
\hline \multirow{8}{*}{\multicolumn{2}{|c|}{ Tidal creeks }} & 33.0 & 3.7 & 6.6 & 71.8 & 193.6 & 18.8 & 3.1 & 4.4 & 1.2 \\
\hline & & 30.5 & 1.3 & 5.9 & 46.4 & 169.2 & 18.0 & 1.9 & 1.2 & 1.7 \\
\hline & & 29.0 & 3.2 & 6.6 & 50.8 & 166.5 & 14.2 & 1.8 & 1.6 & 2.2 \\
\hline & & 28.1 & 1.0 & 6.6 & 33.3 & 171.4 & 13.8 & 1.8 & 12.6 & 1.8 \\
\hline & & 32.7 & 2.2 & 5.9 & 48.1 & 192.2 & 15.1 & 1.9 & 8.1 & 2.7 \\
\hline & & 27.2 & 0.9 & 5.9 & 72.6 & 179.9 & 15.5 & 2.6 & 10.5 & 2.4 \\
\hline & & 27.5 & 2.5 & 6.6 & 54.3 & 151.4 & 10.9 & 2.1 & 43.0 & 2.6 \\
\hline & & 26.0 & 1.6 & 5.3 & 39.4 & 163.1 & 14.3 & 2.0 & 11.4 & 1.9 \\
\hline & Tidal pool & 33.8 & 2.0 & 5.2 & 12.3 & 167.3 & 12.9 & 1.4 & 1.6 & 2.3 \\
\hline \multicolumn{11}{|l|}{ Nov. 2005} \\
\hline \multirow{4}{*}{\multicolumn{2}{|c|}{ Estuarine channel }} & 0 & 0.2 & 4.0 & 6.8 & 19.7 & 0.5 & 0.5 & 1.2 & 0.7 \\
\hline & & 25.6 & 0.3 & 4.2 & 20.5 & 80.9 & 16.1 & 2.1 & 0.5 & 1.5 \\
\hline & & 26.3 & 0.5 & 1.7 & 20.5 & 84.5 & 21.7 & 2.0 & 0.4 & 1.8 \\
\hline & & 27 & 0.4 & 1.5 & 17.1 & 79.4 & 22.3 & 1.8 & 0.8 & 1.9 \\
\hline \multirow{3}{*}{\multicolumn{2}{|c|}{ Tidal creeks }} & 31.2 & 2.7 & 1.5 & 61.4 & 124.4 & 23.4 & 2.3 & 4.1 & 2.5 \\
\hline & & 29.2 & 0.7 & 0.3 & 42.7 & 107.2 & 22.9 & 2.2 & 1.1 & 1.8 \\
\hline & & 28.6 & 0.7 & 0.2 & 44.4 & 120.3 & 21.4 & 2.1 & 5.9 & 2.1 \\
\hline
\end{tabular}




\begin{tabular}{|c|c|c|c|c|c|c|c|c|c|}
\hline & 30 & 1.2 & 0.5 & 47.8 & 112.6 & 23.9 & 2.0 & 6.0 & 1.9 \\
\hline & 28.6 & 0.5 & 1.0 & 47.8 & 108.6 & 22.3 & 1.8 & 5.1 & 2.1 \\
\hline & 27.2 & 0.6 & 0.3 & 35.8 & 116.4 & 21.7 & 1.8 & 13.1 & 1.9 \\
\hline & 28.8 & 1.1 & 0.5 & 42.7 & 100.7 & 21.2 & 2.1 & 10.5 & 2.0 \\
\hline Tidal pool & 32 & 0.6 & 0.2 & 5.1 & 51.8 & 22.6 & 1.4 & 1.0 & 1.7 \\
\hline \multicolumn{10}{|l|}{ J an. 2006} \\
\hline \multirow[t]{4}{*}{ Estuarine channel } & 0 & 0.1 & 113.9 & 12.8 & 19.9 & 0.0 & 0.2 & 1.8 & 0.1 \\
\hline & 4.1 & 0.2 & 113.3 & 10.6 & 62.5 & 2.4 & 0.5 & 1.7 & 0.3 \\
\hline & 6.9 & 0.5 & 112.7 & 25.6 & 95.5 & 5.3 & 0.9 & 2.2 & 0.5 \\
\hline & 8.6 & 0.5 & 44.1 & 21.3 & 94.4 & 4.7 & 0.9 & 1.5 & 0.7 \\
\hline \multirow[t]{8}{*}{ Tidal creeks } & 27.4 & 5.5 & 0.9 & 108.6 & 149.5 & 23.9 & 0.2 & 11.3 & 2.0 \\
\hline & 24.6 & 1.0 & 0.6 & 72.4 & 115.0 & 21.4 & 2.5 & 11.0 & 2.7 \\
\hline & 23.9 & 1.3 & 1.8 & 78.8 & 92.0 & 21.2 & 3.2 & 48.1 & 2.8 \\
\hline & 24.2 & 2.9 & 1.5 & 100.1 & 132.9 & 19.0 & 2.8 & 23.2 & 2.7 \\
\hline & 26.1 & 2.5 & 1.2 & 89.4 & 88.2 & 21.2 & 3.0 & 4.8 & 2.8 \\
\hline & 24.8 & 1.4 & 1.2 & 87.3 & 88.5 & 21.7 & 2.8 & 21.9 & 2.4 \\
\hline & 25 & 1.5 & 1.8 & 61.8 & 65.5 & 19.8 & 2.8 & 7.4 & 1.9 \\
\hline & 24.4 & 2.4 & 1.2 & 83.0 & 85.3 & 22.4 & 2.8 & 47.5 & 2.4 \\
\hline Tidal pool & 27 & 2.8 & 0.3 & 76.7 & 99.7 & 22.6 & 2.9 & 1.4 & 4.2 \\
\hline \multicolumn{10}{|l|}{ Mar. 2006} \\
\hline \multirow[t]{4}{*}{ Estuarine channel } & 0.0 & 0.3 & 89.5 & 2.8 & 28.5 & 0.1 & 0.1 & 8.6 & 0.4 \\
\hline & 2.9 & 0.2 & 54.1 & & 77.4 & 1.0 & 0.6 & 12.7 & 0.3 \\
\hline & 3.8 & 0.7 & 35.1 & 16.5 & 112.8 & 1.3 & 0.5 & 13.5 & 0.6 \\
\hline & 9.8 & 0.3 & 35.4 & 29.0 & 96.0 & 3.2 & 1.1 & 8.6 & 1.3 \\
\hline \multirow[t]{8}{*}{ Tidal creeks } & 23.5 & 0.6 & 0.6 & 125.5 & 115.1 & 16.5 & 3.4 & 10.1 & 3.4 \\
\hline & 20.8 & 0.3 & 0.5 & 128.2 & 101.9 & 14.1 & 3.0 & 7.1 & 3.8 \\
\hline & 19.8 & 1.8 & 0.3 & 144.8 & 112.1 & 17.2 & 2.7 & 13.3 & 3.7 \\
\hline & 20.7 & 0.7 & 0.5 & 107.5 & 97.2 & 14.3 & 2.4 & 53.2 & 4.3 \\
\hline & 21.6 & 2.3 & 0.5 & 144.8 & 99.8 & 14.3 & 3.1 & 27.8 & 5.2 \\
\hline & 20.7 & 0.8 & 0.4 & 111.7 & 107.6 & 14.1 & 2.6 & 54.2 & 4.9 \\
\hline & 20.4 & 3.2 & 0.5 & 111.7 & 101.9 & 14.1 & 3.1 & 31.4 & 5.8 \\
\hline & 19.6 & 1.6 & 1.0 & 92.4 & 97.9 & 12.7 & 3.0 & 82.2 & 4.4 \\
\hline Tidal pool & 22.7 & 3.6 & 0.7 & 133.7 & 122.9 & 15.6 & 3.4 & 29.8 & 3.0 \\
\hline \multicolumn{10}{|l|}{ M ay 2006} \\
\hline \multirow[t]{4}{*}{ Estuarine channel } & 0 & 0.1 & 45.5 & 5.4 & 55.7 & 0.1 & 0.2 & 14.9 & 0.4 \\
\hline & 11.8 & 0.1 & 22.0 & 9.4 & 81.2 & 7.7 & 1.3 & 6.0 & 0.3 \\
\hline & 13.4 & 0.6 & 19.9 & 18.8 & 86.1 & 9.5 & 1.8 & 3.0 & 0.6 \\
\hline & 15.2 & 0.2 & 21.5 & 21.5 & 94.6 & 7.5 & 1.6 & 3.0 & 1.3 \\
\hline \multirow[t]{8}{*}{ Tidal creeks } & 27.5 & 2.5 & 0.5 & 133.2 & 103.6 & 14.6 & 3.8 & 13.0 & 3.5 \\
\hline & 25.8 & 0.6 & 0.7 & 98.2 & 104.7 & 19.4 & 2.8 & 11.1 & 3.8 \\
\hline & 25 & 1.4 & 0.5 & 115.7 & 113.0 & 17.9 & 3.3 & 13.4 & 3.6 \\
\hline & 25.2 & 1.7 & 0.5 & 145.3 & 109.2 & 19.2 & 3.4 & 24.5 & 4.2 \\
\hline & 26.8 & 3.0 & 0.4 & 146.6 & 123.6 & 19.4 & 3.6 & 20.4 & 5.3 \\
\hline & 25 & 0.5 & 0.6 & 111.7 & 107.6 & 18.4 & 3.4 & 22.9 & 4.9 \\
\hline & 25.1 & 2.9 & 0.5 & 106.3 & 136.8 & 18.0 & 3.2 & 37.6 & 5.9 \\
\hline & 23 & 1.0 & 0.6 & 98.2 & 157.4 & 17.6 & 2.9 & 51.4 & 4.4 \\
\hline Tidal pool & 22.3 & 9.2 & 0.5 & 173.5 & 127.4 & 22.0 & 3.9 & 42.5 & 3.0 \\
\hline \multicolumn{10}{|l|}{ J ul. 2006} \\
\hline \multirow[t]{3}{*}{ Estuarine channel } & 0.0 & 0.3 & 45.5 & 29.6 & 43.7 & 1.1 & 0.5 & 4.2 & 0.5 \\
\hline & 10.2 & 0.2 & 22.0 & 44.4 & 188.6 & 6.6 & 2.0 & 3.1 & 0.9 \\
\hline & 14.5 & 0.7 & 19.9 & 90.1 & 217.5 & 10.3 & 2.7 & 2.1 & 1.1 \\
\hline
\end{tabular}




\begin{tabular}{|c|c|c|c|c|c|c|c|c|c|}
\hline & 14.6 & 0.9 & 21.5 & 102.2 & 248.5 & 11.1 & 2.4 & 3.3 & 0.4 \\
\hline \multirow[t]{8}{*}{ Tidal creeks } & 31.2 & 3.4 & 0.5 & 236.8 & 255.0 & 2.5 & 5.6 & 4.2 & 2.0 \\
\hline & 30.5 & 0.5 & 0.7 & 188.3 & 252.9 & 25.4 & 4.1 & 4.0 & 2.0 \\
\hline & 29.0 & 1.2 & 0.5 & 173.5 & 283.9 & 25.4 & 4.0 & 4.0 & 1.8 \\
\hline & 28.1 & 0.7 & 0.5 & 212.5 & 237.7 & 23.4 & 4.7 & 4.4 & 2.4 \\
\hline & 32.7 & 1.7 & 0.4 & 178.9 & 255.0 & 27.1 & 5.7 & 3.9 & 1.8 \\
\hline & 27.2 & 0.9 & 0.6 & 239.4 & 237.7 & 25.7 & 4.3 & 4.8 & 2.4 \\
\hline & 27.5 & 1.1 & 0.5 & 184.3 & 279.2 & 22.9 & 4.4 & 6.4 & 1.6 \\
\hline & 26.0 & 0.9 & 0.6 & 189.7 & 210.2 & 22.8 & 5.3 & 6.7 & 2.6 \\
\hline Tidal pool & 33.8 & 4.3 & 0.5 & 83.4 & 265.9 & 28.3 & 3.4 & 0.1 & 1.1 \\
\hline \multicolumn{10}{|l|}{ Sep. 2006} \\
\hline \multirow[t]{4}{*}{ Estuarine channel } & 0.0 & 0.4 & 4.0 & 7.1 & 31.0 & 0.1 & 0.5 & 1.7 & 0.4 \\
\hline & 12.3 & 0.2 & 6.0 & 18.6 & 154.7 & 6.7 & 1.4 & 1.8 & 1.1 \\
\hline & 15.8 & 0.5 & 6.9 & 32.7 & 229.7 & 8.2 & 1.8 & 0.7 & 1.5 \\
\hline & 28.3 & 1.6 & 1.5 & 50.7 & 163.5 & 17.4 & 2.2 & 0.2 & 1.6 \\
\hline \multirow[t]{8}{*}{ Tidal creeks } & 30.4 & 3.4 & 0.0 & 77.6 & 192.9 & 17.7 & 3.2 & 1.7 & 2.0 \\
\hline & 29.0 & 1.5 & 0.0 & 51.3 & 155.5 & 16.9 & 2.5 & 0.2 & 1.8 \\
\hline & 28.0 & 1.3 & 2.0 & 55.8 & 184.1 & 16.4 & 2.2 & 1.0 & 1.6 \\
\hline & 29.1 & 0.8 & 1.5 & 59.0 & 198.7 & 16.2 & 2.4 & 2.7 & 2.0 \\
\hline & 30.0 & 1.8 & 3.0 & 53.2 & 142.5 & 17.8 & 1.8 & 0.7 & 1.3 \\
\hline & 27.6 & 0.8 & 2.0 & 58.3 & 140.4 & 15.2 & 2.2 & 3.0 & 2.2 \\
\hline & 27.2 & 0.8 & 3.0 & 51.3 & 150.5 & 16.0 & 2.0 & 4.3 & 1.5 \\
\hline & 27.6 & 2.1 & 1.5 & 46.8 & 176.1 & 16.5 & 2.2 & 4.9 & 2.0 \\
\hline Tidal pool & 33.2 & 1.9 & 2.0 & 5.1 & 64.6 & 20.4 & 0.7 & 0.1 & 0.5 \\
\hline
\end{tabular}

